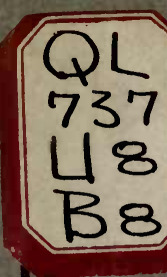

is

\title{
A GUIDE
}

TO THE

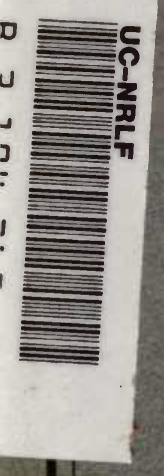

\section{ELEPHA NTS \\ (RECENT AND FOSSIL)}

EXHIBITED IN THE DEPARTMENT OF

GEOLOGY AND PALEONTOLOGY

IN THE

\section{BRITISH MUSEUM (NATURAL HISTORY),}

CROMWELI ROAD, LONDON, S.W.

ILLUSTRATED BY 31 TEXT-FIGURES.

\section{LONDON:}

PRINTED BY ORDER OF THE TRUSTEES OF THE BRITISH MUSEUM.

$$
1908 .
$$


14 BRAR

\section{OF THE}

a $O P$

LIFORNI

EARTH

SCIENCES

HBRARY

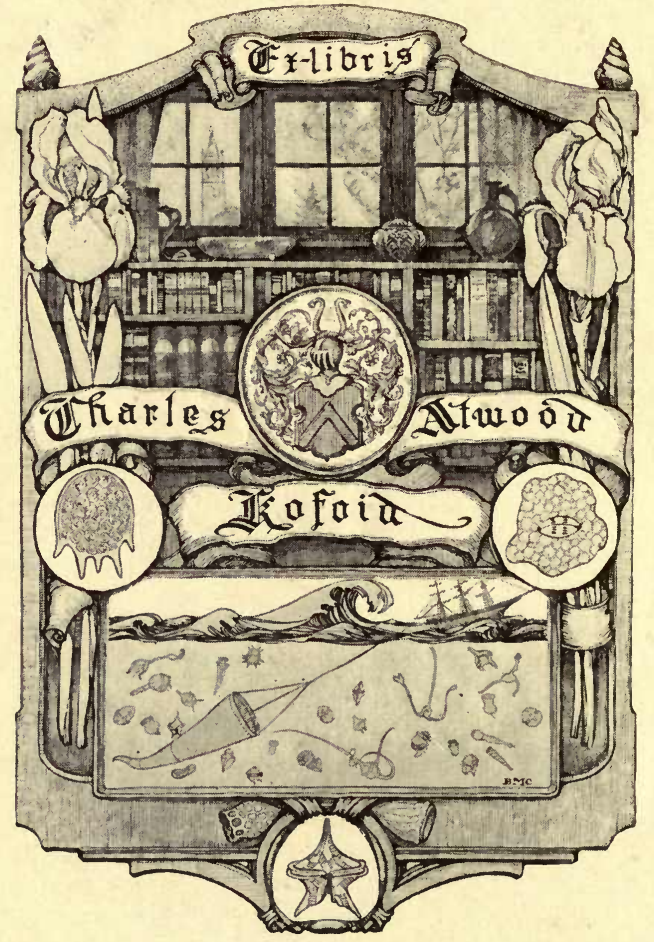




$$
\text { B } 26 \%
$$




\section{A GUIDE}

TO THE

\section{ELEPHAN'TS \\ (RECENT AND FOSSIL)}

EXHIBITED IN. THE DEPARTIENT OF

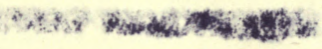

GEOLOGY AND PAL \&ONTOLOGY

IN THE

\section{BRITISH MUSEUM (NATURAL HISTORY),}

CROMWELL ROAD, LONDON, S.W.

$$
\text { C. W. Indrews }
$$

ILLUSTRATED BY 31 TEXT-FIGURES.

\section{IONDON :}

PRINTED BY ORDER OF THE TRUSTEES OF THE BRITISH MUSEUM.

$$
1908 .
$$

(All rights reserved.) 

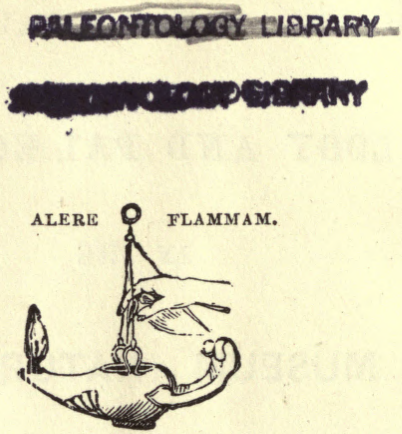

PRINTED BY TAYLOR AND FRANCIS, RED LION COURT, FLEET STREET.

\section{EARTH}

SCIENCES

LIBRARY 


\section{PREFACE.}

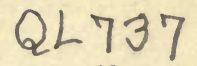

The fossil remains of elephants in the Department of Geology are so numerous, and the ancestral history revealed by them is of so much general interest, that they appear worthy of a special Guide-Book. The present account of the collection has therefore been prepared by Dr. Charles W. Andrews, who has already published technical descriptions of some of the more important specimens in the Philosophical Transactions of the Royal Society (1903 and 1908), and in "A Descriptive Catalogue of the Tertiary Vertebrata of the Fayûm, Egypt" (issued by the Trustees of the British Museum in 1906).

The immediate ancestors of the modern elephants have long been known through the discoveries of Falconer and Cautley in the Pliocene formations of the Siwalik Hills in India; but the earliest members of the group have only been found during recent years in the Eocene deposits of Egypt. The whole of the Cautley Collection is exhibited in the Museum besides other fine specimens from the Siwalik Hills described by Falconer. The Egyptian discoveries also form an extensive collection, though many of the original specimens are in the Geological Museum, Cairo, and only represented here by plaster casts.

Among the illustrations, figs. 1 and 6 are reproduced from the "Encyclopædia Britannica" by permission of The Times.

\section{A. SMITH WOODWARD.}

Department of Geology.

February, 1908.

\section{Мя89861}





\section{G U I D E}

TO

\section{ELEPHANTS (RECENT AND FOSSIL).}

\section{IN THE GALLERY OF FOSSIL MAMMALIA.}

Aт the present day the different main sub-divisions of the Mammalia are, as a rule, very distinctly marked off from one

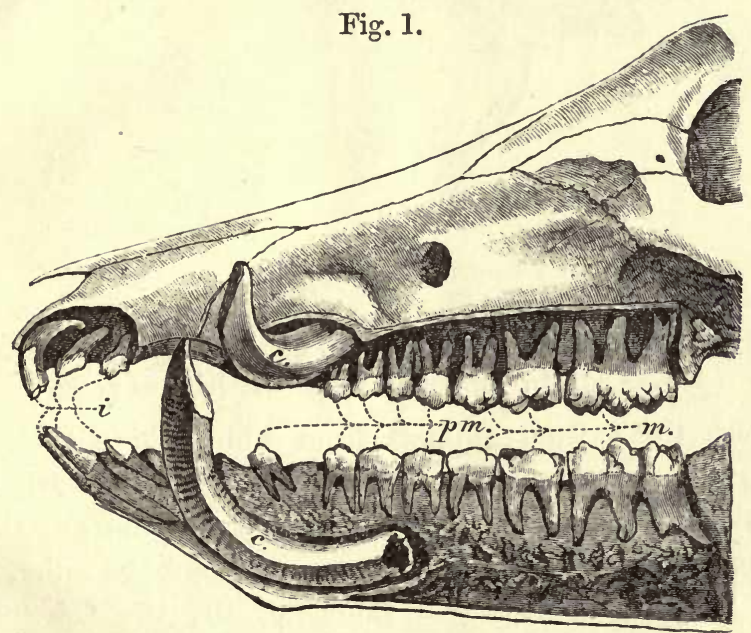

Upper and lower dentition of pig, showing the presence of the full set of 44 teeth and the low-crowned bunodont cheek-teeth adapted for a soft, mainly vegetable diet. $c$., canine; $i$, incisors; $m$., molars ; pm., premolars.

another. For instance, the Carnivora (flesh-eaters, e.g., tiger, bear) are now widely different from the Ungulata (hoofedanimals, e. g., horse and ox), each of these groups being fitted for some special manner of life, and particularly for living on 
some special kind of food. Thus, the principal character of most of the Carnivora is the possession of sharp claws and teeth for killing and devouring other animals; while, on the other hand, the vegetarian Ungulata have teeth fitted for grinding vegetable matter and feet adapted solely for moving: from place to place in search of pasturage. If, however, we trace back through the earlier periods of the Earth's Geological

Fig. 2.

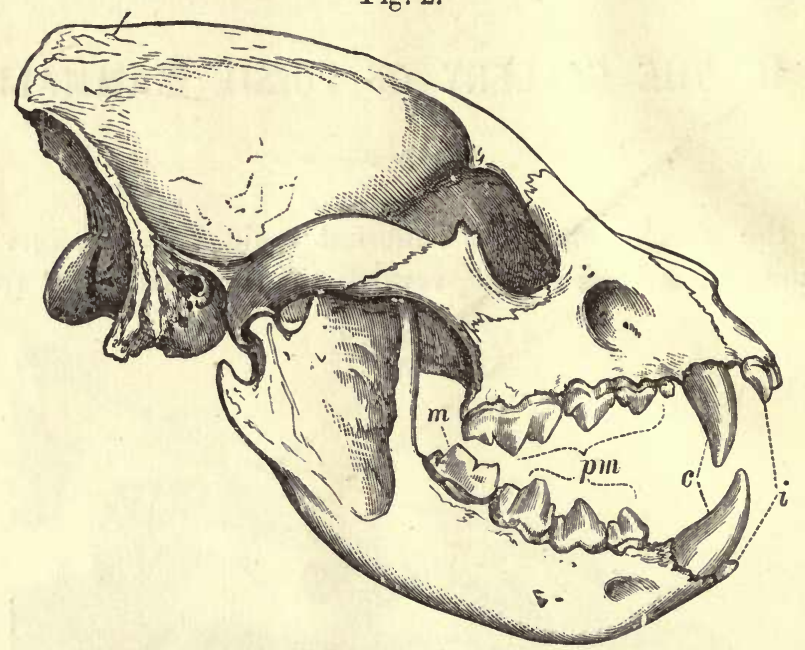

Skull and mandible of Striped Hyæna, showing the sharp cutting cheekteeth adapted for a flesh diet. Lettering as in fig. 1.

History, the extinct animals from which these quite distinct modern groups are descended, we find that in nearly all cases in which these earlier fossil forms are well known, there is a tendency for them to become more and more alike. In the early Eocene, indeed (see table, p. 6), the Carnivora and Ungulata are not always to be distinguished from one another with certainty, so that the animals from which they and some other mammals have descended, may be placed in a single group. Nearly all these early mammals have certain characters in common: thus in most there are five toes on each foot and forty-four comparatively simply constructed teeth. Characters such as these are called "primitive," and when as time goes on they become gradually changed in different ways and adapted for particular purposes, they are said to be more 
"specialised." Thus in the horse the foot (fig. 3) is extremely specialised, in that it has only a single complete toe instead of the primitive number, five : its limbs being specially fitted for swift movement over hard ground. To take another instance, the teeth of the tiger are said to be highly "specialised," because there are only thirty of the original forty-four, and these have become specially adapted for seizing living prey and

Fig. 3.
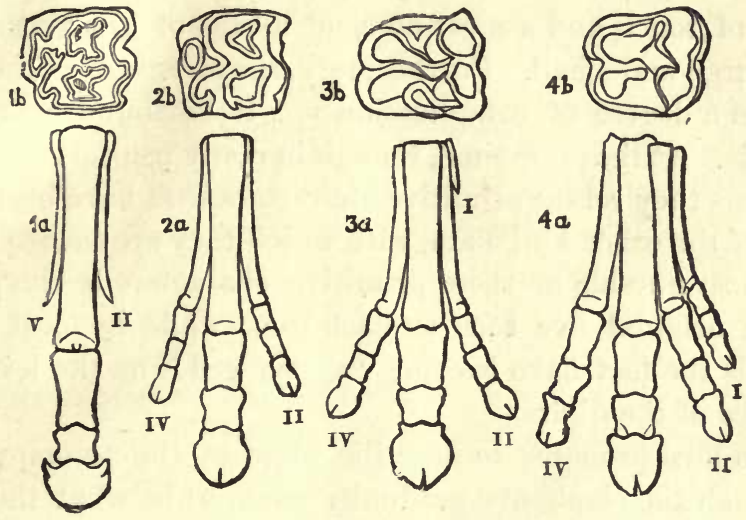

Diagram showing the gradual loss of toes on the fore foot $(a)$ and increase of complexity in the grinding teeth (b) of successive horse-like Ungulata from Europe, namely Hyracotherium (Eocene), 4, Anchitherium (Miocene), 3, Hippurion (Pliocene), 2, Equus (Pleistocene and Recent), 1.

cutting and tearing its flesh. It must be added that all the characters of a group of animals do not necessarily become specialised, but that some may remain in the primitive condition. Thus man, in some ways the most highly specialised of mammals, still retains the primitive number of five digits on both limbs.

In order to trace back a moderu specialised group of mammals to its early primitive ancestors, a long series of fossil remains from the successive geological periods is necessary. Unfortunately in many cases these fossils have yet to be found, but every year further discoveries are made and gaps of more or less importance are filled up. The series of charges undergone by a group of mammals is perhaps best known in the horse 
family*, but recent discoveries of remains of early forms of the elephant-group in the Eocene beds of the Libyan Desert in Egypt, have made it possible to trace the history of the elephants also with considerable completeness, and in the present guide a short account of that history is given.

Among living mammals the elephants are perhaps the most remarkable. Not only do they exceed in size all other living land-animals, but they are further distinguished by the possession of a mobile trunk or proboscis, which is at once a sensitive organ of touch and a most efficient means of grasping objects, both large and small. Furthermore, the structure of their teeth reaches a degree of complication not to be found in any other animals. At the same time, though in many respects so peculiar, in others they retain primitive characters that have been lost in most of the other Ungulata, with which they are usually classed. The most notable of these primitive characters is the presence of the original five toes on each foot, while in most hoofedanimals the feet have become "specialised" by the loss of one or more of the digits.

It is now proposed to describe some of the principal stages by which the elephants gradually came to be what they are at the present day, and to show that the earliest known forms were much like other primitive hoofed-animals, a condition to which the pigs and tapirs among living mammals perhaps most nearly approach. It will be shown that the earliest known animal belonging to the Proboscidea or elephants was, in fact, not unlike a large pig (see fig. 8), though in some respects an even more primitive creature. From this beginning we can trace a gradual increase in size in the later forms, a gradual development of the trunk or proboscis, first as the upper part of a long snout supported by the elongated lower jaw, afterwards as the familiar movable organ so characteristic of the modern elephants. We can also observe the gradual increase in the size and degree of complication of the grindingteeth, accompanied by the complete loss of many of the teeth

* Casts of specimens showing the gradual " specialisation" of the teeth and feet in the horses are shown in a case in the North Hall. See also pier-case 10 and table-case 5 in Gallery of Fossil Mammals. 
Fig. 4.

Recent

Pleistocene

ELEPHAS

Unper Pliocene (short chin)

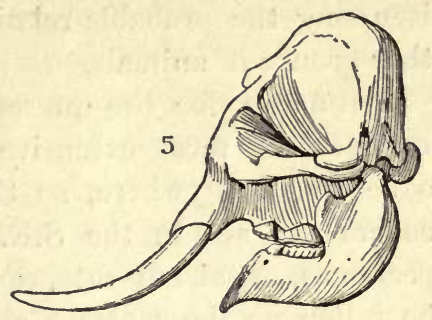

Lower Pliocene

TETRABELODON [LONGIROSTRIS STACE]

Upper Miocene (shorteningchin)

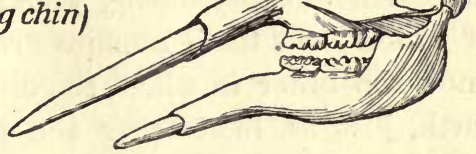

Middle Miocene

TETRABELODON [ANGUSTIDENS STAGE]

Lower Miocene (longchin)

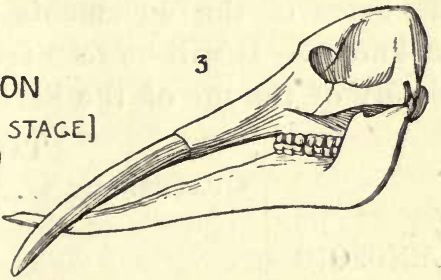

$\begin{array}{ll}\text { Upper Oligacene } & \text { Migration from Africa } \\ \text { into Europe-Asia }\end{array}$ 
found in the earlier forms. Finally, we have materials for discussing the probable relationship of the elephants to some other groups of animals.

Fortunately for the present purpose the British Museum possesses the most extensive series of Proboscidean remains to be found anywhere, so that except in very few instances readers can see in the S.E. Gallery of Geology the actual specimens, or, at any rate, casts of the specimens, upon which the following descriptions are based, and can to some extent check the accuracy of the various statements for themselves.

Before proceeding to the description of the animals, it may be advisable to refer to the geolcgical horizons or periods of the Earth's history during which they existed and in the rocks of which their fossil remains are found; for it is necessary to know the order in which the different forms appeared on the earth, just as in tracing the pedigree of a human family, the dates of the documents upon which it is founded must be known. It will be seen from the following table that the history of the life of the Earth falls into sereral great periods

TABLe 1.

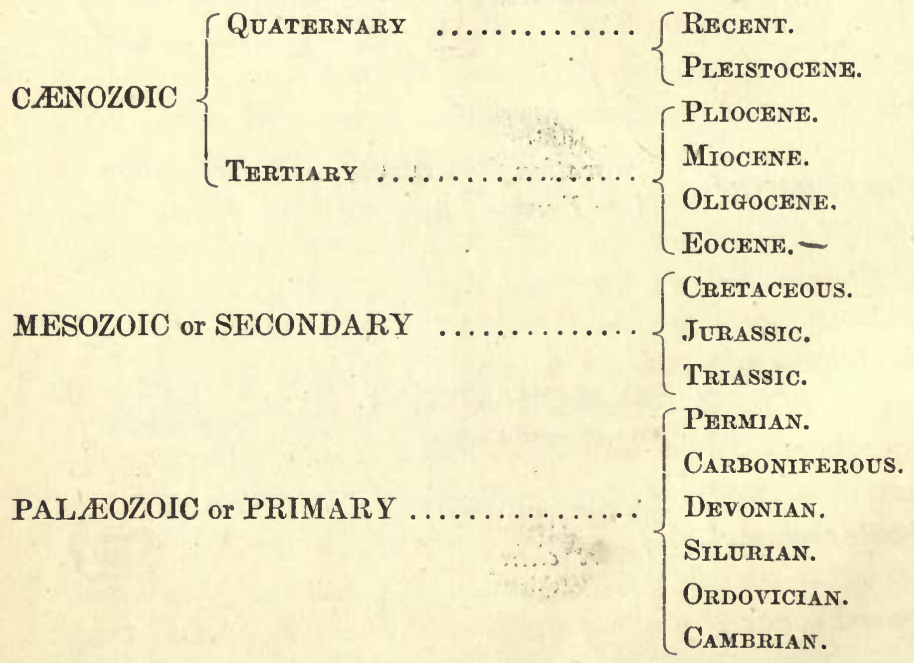

to which names have been given by geologists. The earliest of these is called the Primary or Palæozoic Period, and during 
it the only backboned animals were fishes, amphibians (represented at the present time by newts, frogs, \&c.), and, towards the end, some reptiles. In the next great period, the Secondary or Mesozoic, the reptiles were of the greatest importance : they were very numerous and some were of gigantic size. They became fitted for various modes of life, some inhabiting the land, others the sea; some living on a vegetable diet, others on flesh. During this period also the birds began to come into existence, and remains of the most remarkable of the early forms of birds, Archeopteryx, are shown in table-case 13. At the same time the first of the warm-blooded mammals arose, though they were as yet insignificant in size and numbers. The third period, the Cænozoic, is that with which we are chiefly concerned. During it the reptiles became of little importance, while, on the other hand, the mammals took their place, becoming extremely numerous, many of them of great size, and adapted to every kind of life and food. The latter part of this period, sometimes called the Quaternary, extends till the present day, and during it the mammals still continue to be the prominent backboned animals, but one of them, man, has become by far the most important inhabitant of the world, and instead of merely being slowly fitted to new conditions of life, now to a large extent controls the conditions and changes them to suit his own convenience.

The second table (p. 8) shows what are the chief forms of Proboscideans living at the different periods and their distribution over the world. It will be seen that the earliest mammal which can be definitely called a Proboscidean is Moeritherium, a small tapir-like creature from the Middle Eocene beds of the Fayûm district of Egypt. This species existed also in the Upper Eocene of the same region, but was then accompanied by a larger and much more elephantlike animal, Palaomastodon. At this time Africa was cut off from the rest of the world to the north by a broad and deep sea which extended from the Atlantic to the Pacific by way of Northern India and Southern China, and the separation of Africa prevented these early forms of elephant from wandering into other regions till after the Eocene.

After Palcomas. 
ELEPHANTS.

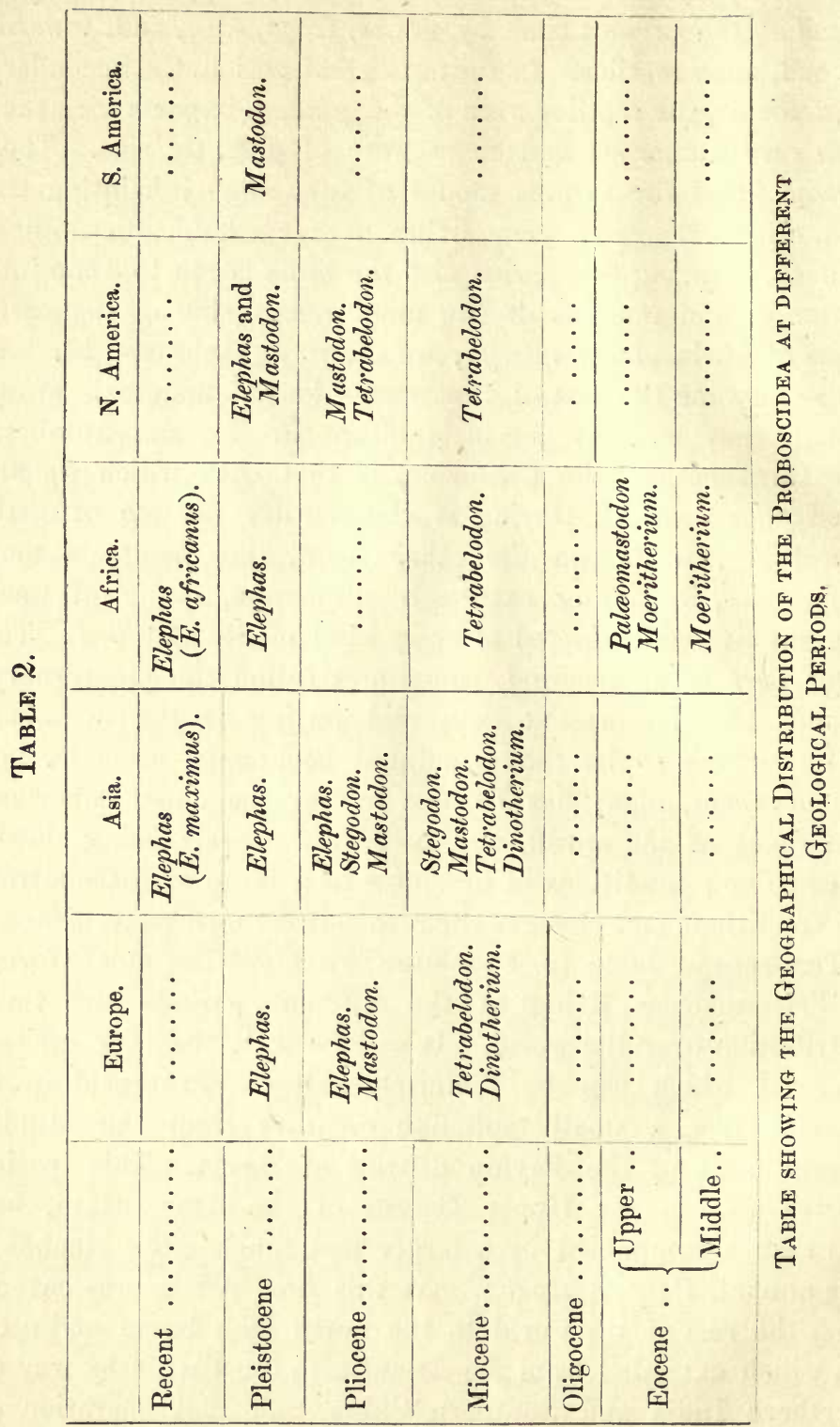


todon there is a large gap in the series, no fossil Proboscidea having yet been found in the Oligocene, though no doubt their remains will be discovered somewhere in the freshwater deposits of that age in Egypt. Hitherto no Proboscidean bones and teeth have been met with again till the Lower Miocene, but in rocks of that period they are found abundantly, not only in Egypt, but in Europe, Asia, and North America. It is therefore clear that during the long lapse of time after the Eocene, the deep sea above referred to, must to some extent have been replaced by land, over which the early elephants could spread outwards from their home in Africa. The vast changes in the distribution of land and water that took place in this region, will be apparent when it is understood that rocks crowded with the shells that lived at the bottom of this ancient sea are to-day found thousands of feet above the sea-level in India and elsewhere.

From the Lower Miocene period onwards we meet with elephant-like animals in great variety all over the Northern Hemisphere, wherever suitable deposits for the preservation of their remains occur. At the end of the Pliocene period the group also spread into South America, but at the present day it is totally wanting in the whole Western Hemisphere.

During the later Miocene and Pliocene periods the headquarters of these animals seem to have been in India, for it is there that we meet with the greatest number and variety of forms, showing all grades of structure between the Miocene types above referred to and elephants almost like those now existing. From the end of the Pliocene to the beginning of the Quaternary Period may be regarded as the time during which the elephants reached their most flourishing condition, both in the number of kinds that existed and in the wide range over which they were spread. After this a gradual decline in the group took place, till, at the present day, it is represented by two species only, the African elephant confined to Tropical Africa, and the Indian elephant found in India, Ceylon, Burma, the Malay Peninsula, and some of the neighbouring islands. But for restrictions placed upon their slaughter even these last remuants of one of the oldest, and in many 
ways the most remarkable, groups of mammals would soon disappear, just as has happened for instance, in the case of the great ground-sloths of South America, the giant lemurs of Madagascar, and the giant marsupials such as Diprotodon in Australia.

A more detailed account of the changes that the Proboscidea have passed through will now be given, the following animals being selected for description as representing six of the most important of the successive stages at present known.

1. Moeritherium lyonsi, Middle and Upper Eocene.

2. Palceomastodon beadnelli, Upper Eocene.

3. Tetrabelodon angustidens, Miocene.

4. longirostris, Lower Pliocene.

5. Stegodon insignis, Pliocene.

6. Elephas, Pliocene, Pleistocene, and Recent.

Some reference will also be made to other types, such as Dinotherium and Mastodon.

Wall- Moeritherium (figs. 5, 7,8) was an animal abont the size of a case 43. large Newfoundland dog, or of the tapir, which it must have Tablecase 24 . much resembled in general appearance. It was common in the region that is now known as the Fayûm in Lower Egypt, where its fossil remains occur in considerable quantities in the Middle Eocene beds, intermingled with bones of toothed whales (Zeuglodon), sea-cows (Eosiren), marine turtles (Psephophorus and Thalassochelys), and snakes (Pterosphenus), as well as skeletons of fishes. From this mixture of land and aquatic animals it may be concluded that Moeritherium lived near the shore, probably in swamps at the mouth of a great river, where the remains of both marine and of drowned landanimals would be mingled and entombed together in the muds and clays, which accumulated in the estuary. and now make up much of the strata found in this locality. In the Upper Eocene beds, overlying those just described, remains of Moeritherium are also found; here, however, there is no intermingling of marine animals, but instead we find remains of many remarkable land-mammals, crocodiles, and immense 
quantities of trunks of fossil trees, embedded in the sands and gravels of a great river. Probably both the animals and the tree-trunks were swept away by floods, their remains piled up in shallows and places where the current was slack, and buried in the mud and sand carried down by the stream.

The skull of the Moeritherium (see fig. 5) differs in no

Fig. 5.

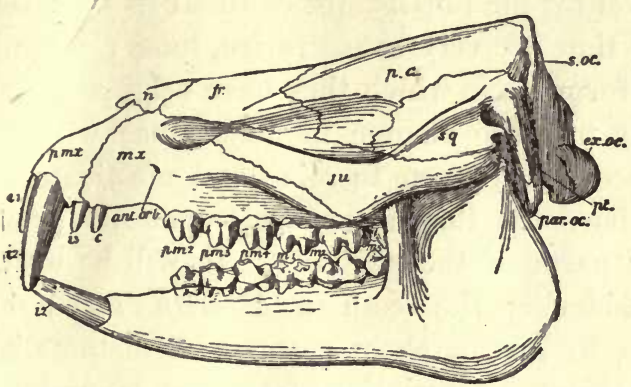

Skull and lower jaw of Moeritherium from the Middle Eocene of the Fayûm, Egypt. $\frac{1}{7}$ nat. size.

ant.orb., antorbital foramen; c., canine ; ex:oc., exoccipital ; fr., frontal; $i .1-3$ incisors; $j u$., jugal; $m .1-3$, molars; mx., maxilla ; n., nasal ; p.a., parietal; par., paroccipital; pm. 2-4, premolars ; p.m.r., premaxilla; pt., post-tympanic process of squamosal ; s.oc., supraoccipital; sq. squamosal.

very marked manner from that of other primitive hoofedanimals, and shows scarcely any trace of the peculiarities of the skulls of the later Proboscidea. The most important feature is the large nasal opening not quite at the end of the snout, the nasal bones being short; this indicates that probably there was already a short proboscis, something like that of the tapir. Another interesting point is that some of the bones at the back of the skull are thickened and contain air-chambers; in the later elephants this development of air-cells is carried to such an extent that the whole form of the skull, particularly the posterior portion, is entirely altered by it (see the broken skull of the Indian elephant, stand G in Gallery). The reason for this swelling of the bones is, that as the head becomes heavier, owing in great part to the development of the trunk 
and tusks, a larger surface for the attachment of the muscles which support the head is necessary, and even in the small Eocene Moeritherium change in this direction had begun.

In the fossil mammals it is the teeth that are of the greatest importance in settling the relationships of different species to one another, and in forming an opinion as to their food and probable manner of life.

The reason for the importance of fossil teeth is, that while in many ways they are very conservative, long retaining traces of the earlier forms from which they have originated, nevertheless they readily undergo change in accordance with the kind of food they are called upon to seize and masticate. Moreover, from their hardness they are more frequently preserved than most other parts of the skeleton. It will be well, therefore, before considering the teeth of Moeritherium and the other Proboscidea to give a short account of mammalian teeth in general, so that the descriptions later may be understood.

Central Hall, Bay I. The tooth of a mammal (see Mammalia in Index collection in Central Hall) consists of a root or roots embedded in a socket in the jaw, and a crown which is exposed and is adapted for the work it has to perform. In a section of a tooth (fig. 6) it is seen that the greater part is composed of a hard material called dentine, and that the crown of the tooth is usually covered with a still harder substance known as enamel, while in some cases the root, and in others (usually the more complicated forms) both root and crown, may be coated with a softer bony matter, called cement. The form of the crown differs enormously in different animals and in different parts of the mouth : it may be a simple cone like the canine or dog-tooth, or it may form a large complicated grinding surface as in the back teeth of the horse. The teeth are usually divided into different series according to their particular position in the mouth and the duties they have to perform (see figs. $1 \& 2$ ). The front teeth implanted in the anterior part of the jaw are mainly concerned in grasping and biting off the food: these are called incisors. In mammals which, like the pig (fig. 1), possess the primitive number of teeth, there are three of these on either side in both upper and lower jaws. Behind these come the 
canines, one on each side above and below ; these are generally Central more or less pointed teeth, serving chiefly for fighting or defence. Hall,

Bay I.

Fig. 6.
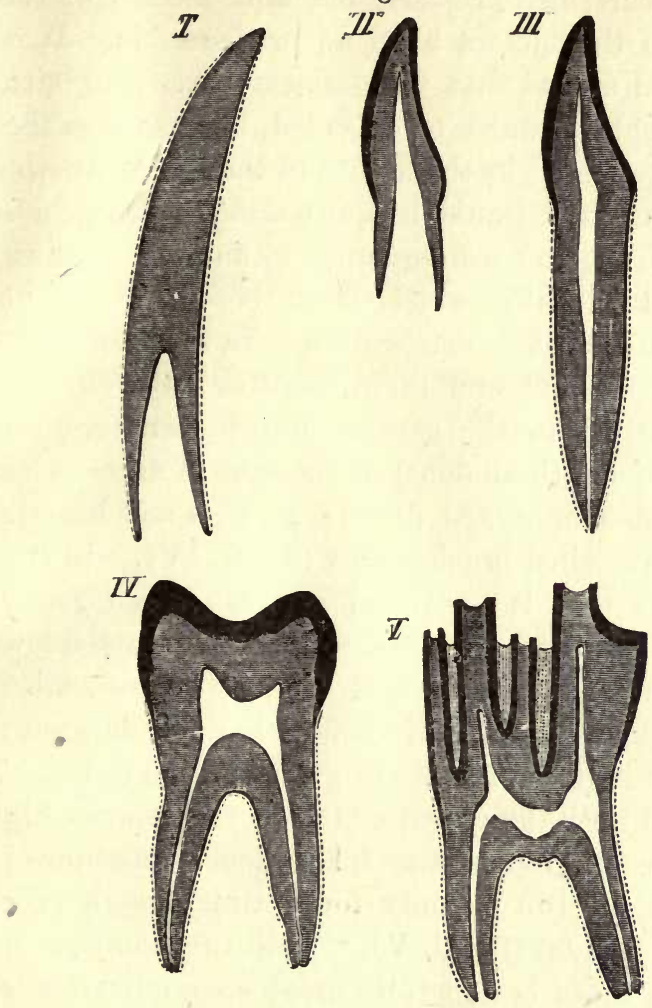

Diagrammatic section of various teeth.

1. Section of tusk of elephant, a permanently growing tooth. II. Section of a young human incisor still growing, the root not yet fully formed. III. Section of human incisor fully formed, the root being complete. IV. Section of human molar showing the low-crowned (brachyodont) condition, the cusps being rounded tubercles (bunodont). V. Section of the molar of an ox, showing the high (hypsodont) complexly folded crown. In the figures the enamel is black, the pulp white, the dentine represented by horizontal lines, the cement by dots.

Behind these again are the cheek-teeth which have to do mainly with the breaking up of the food before it is swallowed: in the 
Central complete dentition there are seven of these on either side in both Hall, Bay I. jaws and they are divided into two groups, (1) four premolars in front, and (2) three molars behind: the premolars, or at least those posteriorly, replace the milk-molars of the young animal, while the molars have no predecessors. It is in the premolars and molars that the greatest variety of structure is found, as might of course be expected, because it is these teeth that are most affected by the nature of the food. Teeth suitable for cutting up flesh would be quite unfitted for grinding hard vegetable matter, and consequently in animals feeding on soft material the teeth differ widely from those in which the food is hard and requires much mastication. In the former the crowns of the teeth are low and their cusps or tubercles are either sharp and cutting in the case of flesh-feeders (e.g., lions and tigers) or rounded (bunodont) in the case of animals feeding on a soft vegetable or mixed diet (e.g., pigs and bears). Teeth of this sort are called brachyodont (fig. 6, IV). In the case of animals whose food is hard and requires much grinding, the wear of the teeth is so great that simply-constructed low crowns would be quickly worn out, and it must be remembered that the length of an animal's life is largely dependent on the time during which its teeth remain in good working order. To meet the increased wear the crown of the tooth becomes higher and moves up in the gum as wear takes place, sometimes throughout the animal's life or only for a time; teeth of this sort are called hypsodont (fig. 6, V). With this increase in height of the crown there is generally greater complication resulting from the infolding of the enamel in various ways, and the development of cement on the crown as well as on the roots. One example of this gradual increase of height and complication is about to be described in the case of the elephants; another extremely good instance is found in the gradual evolution of the teeth in the horses, as excellently illustrated in the case in the North Hall and in table-case 8 (see fig. 3).

From the above account it will be seen that when the full number of teeth is present there are three incisors, one canine, four premolars, and three molars on each side in the upper jaw, and the same in the lower jaw. This is usually expressed shortly 
by a formula, thus :-I. $\frac{8}{3}, \mathrm{C} . \frac{1}{1}, \mathrm{Pm} .{ }_{4}^{4}, \mathrm{M}_{\frac{3}{3}}=\frac{11}{11}$, the letters denoting the kind of teeth, the upper numbers the number of each kind on one side in the upper jaw, the lower numbers those in the lower jaw, so that in the example above given there would be eleven teeth on each side in both the upper and lower jaws, or forty-four in all. As has already been mentioned, a greater or less number of these teeth may be wanting in different animals and the formula will differ accordingly: thus in man it is I. $\frac{2}{2}$, C. $\frac{1}{1}, \mathrm{Pm} . \frac{2}{2}$, M. $\frac{3}{3}=\frac{8}{8}$ or thirty-two in all. In the cat it is I. $\frac{3}{3}$, C. $\frac{1}{1}, \mathrm{Pm} \cdot \frac{3}{2}, \mathrm{M} \cdot \frac{1}{1}=\frac{8}{7}$ or thirty in all.

With these preliminary remarks we may proceed to describe

Fig. 7.
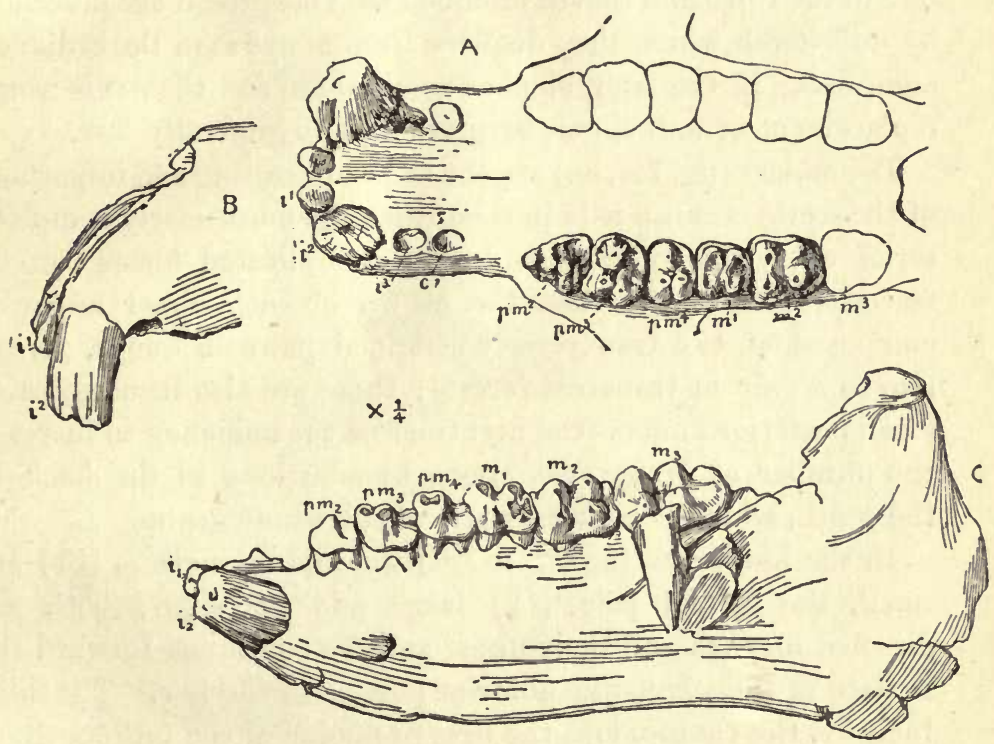

Upper and lower teeth of Moeritherium.

A. Upper teeth. B. Premaxilla, large tusk-like second incisor. C. Mandible from outer side. $c$., socket of canine ; $i .1-3$, incisors; $m .1-3$, molars; pm. 2-4, premolars. $\frac{1}{4}$ nat. size.

the teeth of Moeritherium (figs. 5 \& 7). In this animal the dental formula is $\mathrm{I} .{ }_{2}^{3}$, C. $\frac{1}{0}, \mathrm{Pm} . \frac{3}{3}, \mathrm{M} . \frac{3}{3}=\frac{10}{8}$ or thirty-six in all.

Wallcase 43. Tablecase 24. 
Wall- From the formula it will be seen that in the upper jaw only one case 43. Tablecase 24 .

premolar is wanting to complete the primitive number, while in the lower jaw an incisor and the canine are missing on each side in addition to the premolar.

Of the upper incisors the second pair (i.2) are greatly enlarged and form strong downwardly directed tusks, the beginning of the great tusks so characteristic of the later elephants. The canine (c.) seems to have been quite small and unimportant, being on the way to disappearance. The premolars $(\mathrm{pm}$.$) are separated from the canine by a short interval,$ and as already mentioned the anterior one of the full dentition is wanting. The remaining premolars are all simpler in structure than the molars behind them, and consist of three main cusps only, the two front cusps being arranged in a transverse line in the third and fourth premolars. These teeth are preceded by milk-teeth which they displace from above as in the ordinary mammals; in the later elephants we shall see that this usual replacement of milk-teeth by premolars is gradually lost.

The molars (fig. $7 \mathrm{~A}, m$.) are the most interesting and important of the teeth, because it is in them that the most nearly complete series of gradually more and more complicated forms can be traced. In Moeritherium the crown of each upper molar is composed of two transversely arranged pairs of knobs, giving rise to a pair of transverse crests ; there are also in many cases small posterior knobs-the first trace of the tendency to increase the number of transverse crests by additions to the back of the tooth, which is characteristic of the whole group.

In the lower jaw (figs. $5 \& 7 \mathrm{C}$ ) the middle incisors $(i 1)$ are small, the second pair ( $i 2)$ large and tusk-like; both are directed forward and their upper surface continues forward the surface of the spout-like anterior portion of the jaw. The third incisors, the canine, and the first premolar of the full dentition are wanting. The remaining three premolars $(p m$.$) , which re-$ place milk-molars, are simpler than the molars, and only in the third and fourth is there any arrangement of the anterior cusps to form a transverse ridge. The first and second molars (fig. $7 \mathrm{C}$ ), like those of the upper jaw, consist of two transverselyarranged pairs of knobs and a posterior knob which is larger 
than in the upper teeth. The last lower molar (fig. 10 A) has third ridge forming a sort of heel or talon, as it is called; this

Wall- : case 43.

Table-

case 24.

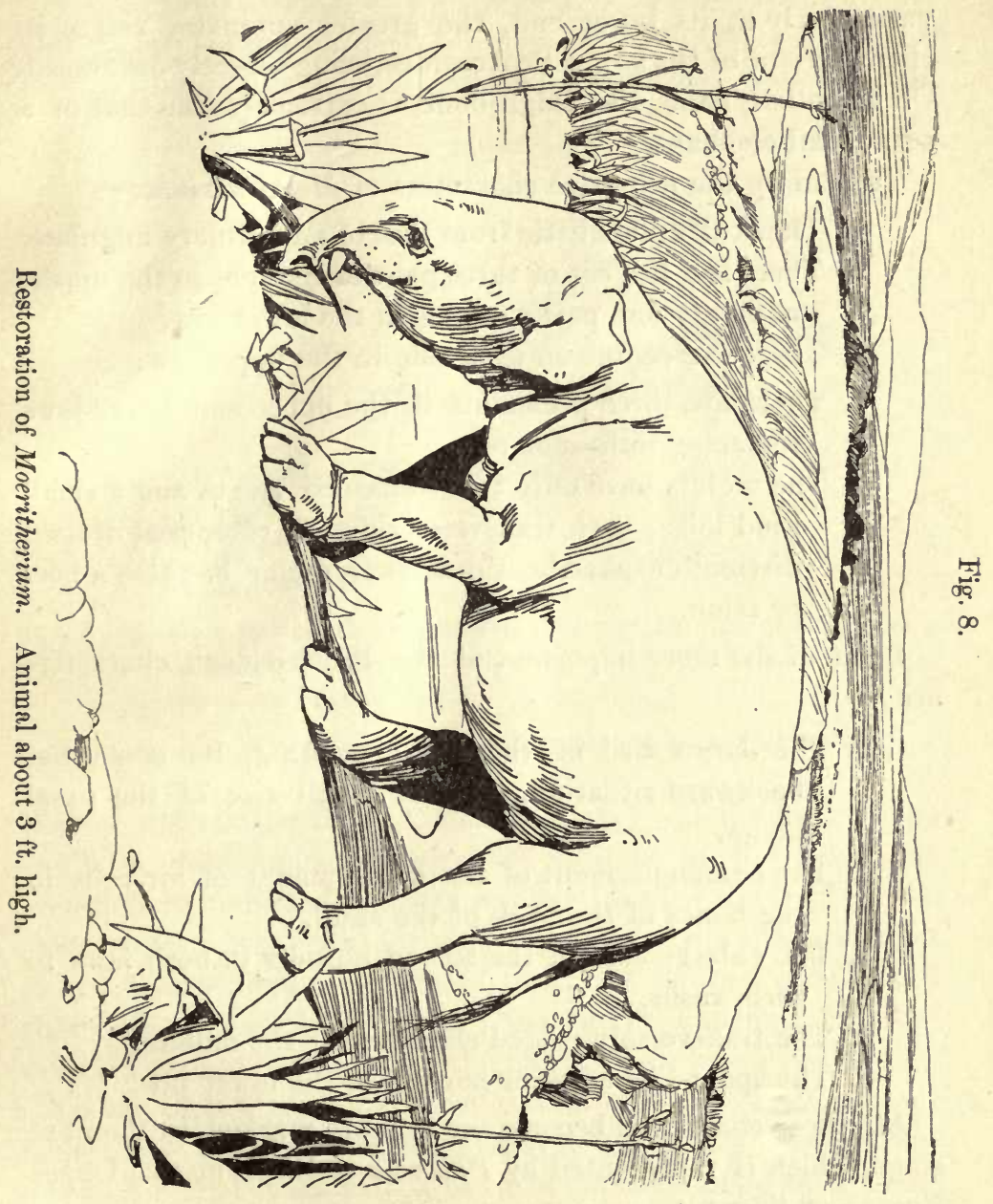

tooth, though much smaller, is remarkably similar to the molars of some of the earlier forms of Mastodon.

The skeleton of Moeritherium is not well known, but some of the more important points in its structure are:-(1) the neck is proportionately longer than in the later elephants in which it 
Wall- is much shortened, (2) the hip-bones are narrow, while in the case 43 . later forms, owing to the great increase in size and weight, they Tablecase 24. are much expanded. The humerus also is rather different, particularly at its lower end, the greater supinator ridge, so characteristic of the larger Proboscidea, being scarcely developed. On the other hand, the thigh-bone is extremely like that of a very small elephant.

To sum up the primitive characters of Moeritherium :-

1. The skull differs little from that of an ordinary ungulate.

2. There is a full set of three pairs of incisors in the upper, and only one pair wanting in the lower jaw.

3. There is a canine on each side in the upper jaw.

4. There are three premolars in the upper and lower jaws replacing milk-molars.

5. The molars have only two transverse ridges and a small hind lobe ; each transverse ridge is composed of two distinct cusps; the third lower molar has also a heel or talon.

Some of the more important of the Proboscidean characters are :-

1. The large size of the nasal opening, its somewhat backward situation, and the small size of the nasal bones.

2. The commencement of the development of air-cells in the bones of the back of the skull.

3. The enlargement of the second incisors in both jaws to form tusks.

4. The transversely ridged character of the molars.

5. The spout-like anterior portion of the lower jaw.

All these characters become much more marked in the next stage, which is represented by Palaomastodon from the Upper Eocene of Egypt.

The genus Palcomastodon (figs. 9-11, 13) is represented by several species varying in size from an animal little larger than Moeritherium to one nearly as large as a small elephant, so that in the matter of size alone there is a great advance in the direction of the modern elephants. In the 
structure of the skull and teeth, as well as in the rest of the skeleton, so far as known, the advance is likewise very striking. In the skull (see fig. 9) the opening of the nostril (nar.) has shifted far back from near the end of the snout, though it is still in front of the orbit of the eye. The nasal bones are still

Wallcase 43. Table-case 24.

Fig. 9.

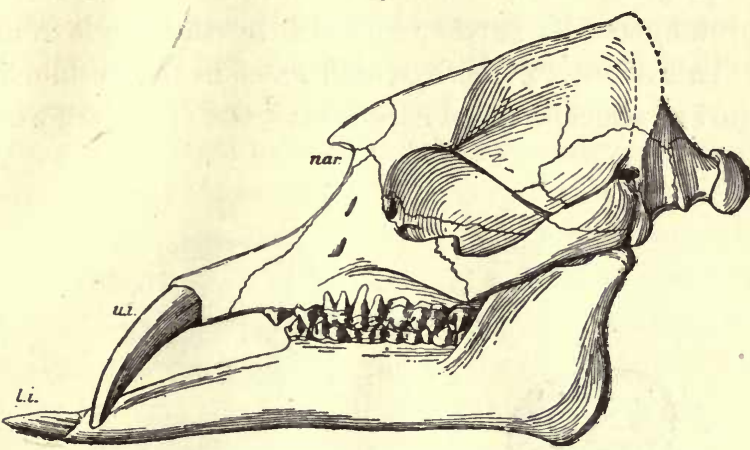

Skull and lower jaw of Palcoonastodon, showing the elongated chin with a pair of terminal incisors (l.i.), from the Upper Eocene (? Lower Oligocene) of the Fayûm, Egypt. $\frac{1}{12}$ nat. size.

uar., position of opening of nose ; $u . i$., upper second incisor or tusk.

shorter and smaller than in Moeritherium. At the back of the skull the development of air-cells in some of the bones has enormously increased, but has not yet invaded the roof of the skull, so that the sides are only separated by a sharp median crest. The posterior surface of the skull slopes forward, and there is a deep pit in the middle line for the attachment of the muscles necessary to support the increasingly heary head.

Of the incisor teeth only the second pair now remains, and these have been still further enlarged, forming downwardly directed curved tusks with a band of enamel along their outer sicies only. The canine has disappeared, but there are still three premolars replacing milk-moląrs. The anterior premolar is a simple cone, while the crown of the posterior one consists of two transverse ridges, these teeth being subjected to two distinct influences, namely, the tendency to the reduction in the front of the series, and the tendency to become more like the 
Wall- molars at the back. The molars themselves show a distinct case 43. advance, the crown of each consisting of three transverse ridges, Table- 24 . each ridge composed primarily of two main cusps which may, however, show small traces of sub-division into secondary cusps.

The mandible (figs. $9 \& 13$ ) differs from that of Moeritherium in the much greater prolongation of the spout-like anterior portion; this now projects a considerable distance in front of the skull and is prolonged still further forward by the single remaining (second) pair of incisor teeth, which meet in the middle line and. form a sort of shovel-shaped extension; the edges are worn both

Fig. 10.
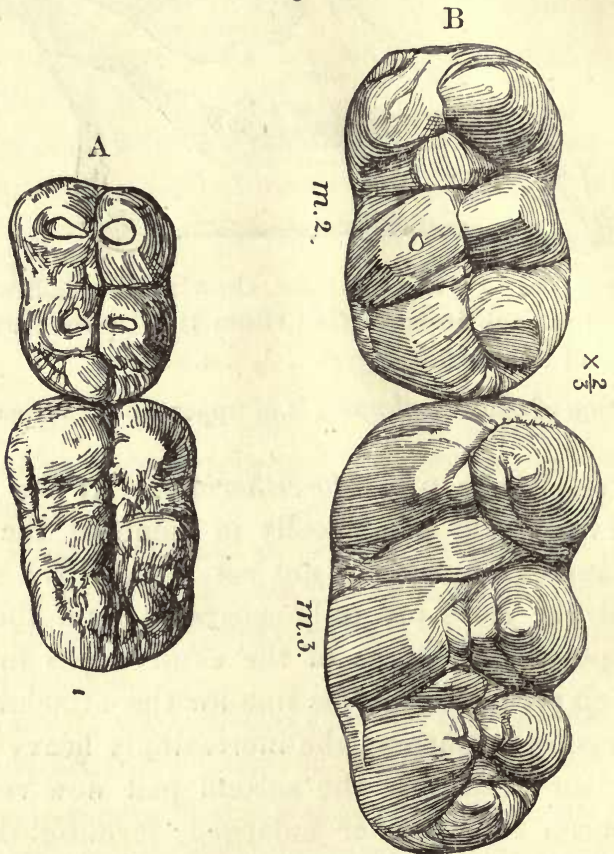

Posterior lower molars $\left(m_{2}, m_{3}\right)$ of (A) Moeritherium and (B) Palcomastodon, showing the increase in the number of ridges of Palaomastodon. $\frac{2}{3}$ nat. size.

on the upper and lower surface, so that these teeth were probably used for grubbing about in the ground to procure food, and the upper surface must have been further worn by working: against the lower surface of the trunk or elongated upper lip. 
There are only two premolars in the lower jaw, the anterior of the three milk-molars (figs. 9 \& 13) falling out without being replaced from below; the molars are three in number, the two anterior with three transverse ridges, the third sometimes having in addition a small heel (fig. 10). It should be noticed that in the full-grown animal all the molars and premolars are in position and use at the same time; it will be seen that in the later forms of elephant-ancestors this is not so.

The skeleton, so far as known, is almost exactly like that of a small elephant, the only important differences being that the neck is longer and the limbs most likely less massive. The animal as a whole (fig. 11) must have been very like a small elephant, but would be distinguishable by the longer head and neck, and by the fact that instead of possessing a flexible trunk it had a long snout, the lower portion consisting of the elongated lower jaw, the upper without bony support and probably extending beyond the lower; the projecting portion most likely was more or less flexible and capable of seizing objects, and was the beginning of the prehensile trunk.

The chief steps taken by Palaomastodon in advance of Moeritherium towards greater likeness to the later elephants are :-

1. Considerable increase in size.

2. Lengthening of the snout, as shown by the mandible.

3. Loss of canines and all the incisors except the second pair in both jaws.

4. Three-ridged molars.

5. Greater development of air-cells at back of skull.

6. Shifting further back of the nose-opening and smaller size of the nasal bones.

7. Greater similarity of the bones of the skeleton to those of ordinary elephants.

The next stage is found in Tetrabelodon angustidens (figs. 1214), from the Lower Miocene of Northern Africa, Europe, and probably Asia. This animal is as large as a medium-sized elephant, and its teeth and skull are much more elephant-like Piercases $41,42$. Tablethan in Palcomastodon. Thus the nostrils have shifted still further back, and the great development of air-cells in the bones

Wallcase 43. Tablecase 24. 


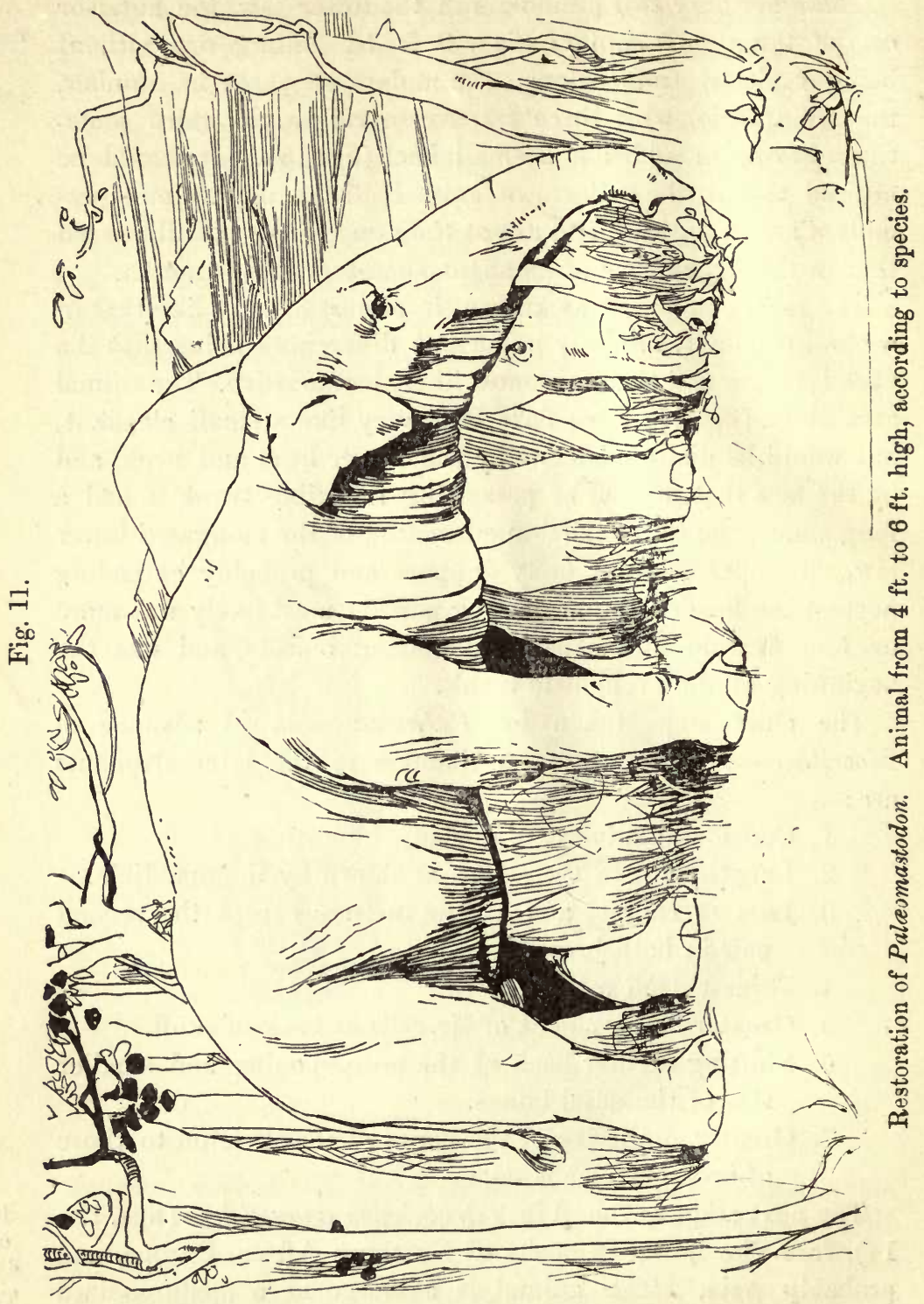


at the back of the skull has led to the disappearance of the ridge along the middle of the roof, which is now flat. Further, the tusks, which were quite small and flattened in Palcomastodon, are now large and round, and differ from those of a modern elephant only in curving downward instead of upward, and in having a band of enamel along the outer side relatively much narrower than in Paleomastodon, in which nearly the whole

Fig. 12.

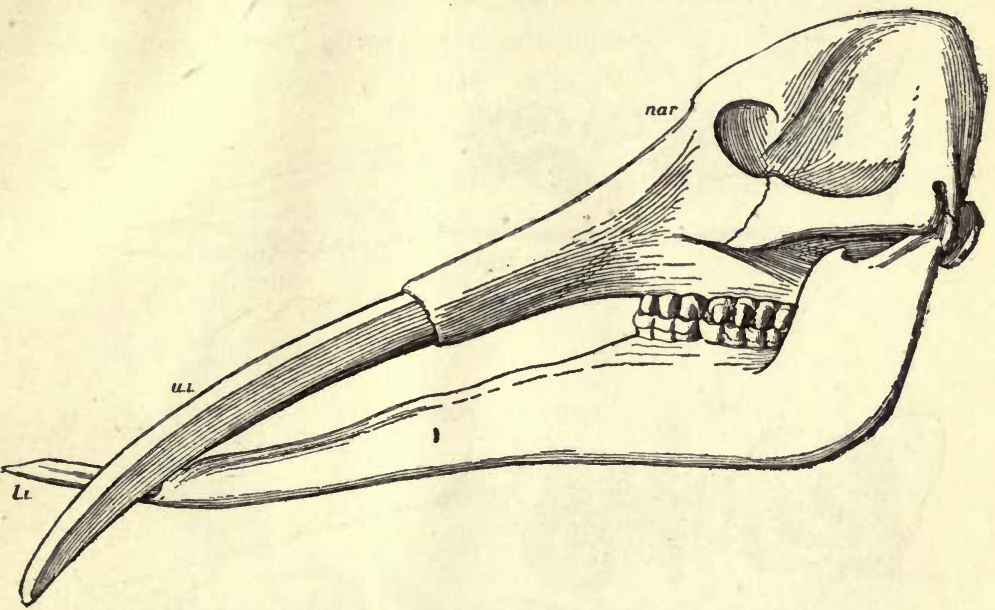

Skull and mandible of Tetrabelodon angustidens, showing the greatly elongated chin with a pair of terminal cutting incisors (l.i.), from the Lower and Middle Miocene, France. $\frac{1}{20}$ nat. size.

nar., position of opening of nose ; $u, i$., upper incisors.

outer face of the tooth is enamel-clad. As the tusks increase in size, the dentine of which they are composed acquires a peculiar structure, which is shown in transverse sections of the tusks (see table-case 24) and appears as a series of crossing lines curving out from the middle of the tooth and giving a pattern like the engine-turning on the case of a watch. This is quite peculiar to elephant-tusks, and by it even small pieces of ivory can be at once distinguished. This structure depends on the frequent bending of the tubules which make up the dentine, and one result of it is, that ivory is one of the most perfectly elastic of substances, and is therefore specially suitable for making billiard balls. 
Pier- This form of ivory is not found in either the upper or lower tusks 41, 42. of Mueritherium and Palcomastodon or in the lower tusks of Table- Dinotherium, and appears for the first time in the large upper cases 23,24 . tusks of Tetrabelodon angustidens. In some of the American Tetrabelodonts in which the lower tusks are very large, this structure is also found in them.

In the lower teeth also of Tetrabelodon angustidens (fig. $16 \mathrm{~A}$ )

Fig. 13.
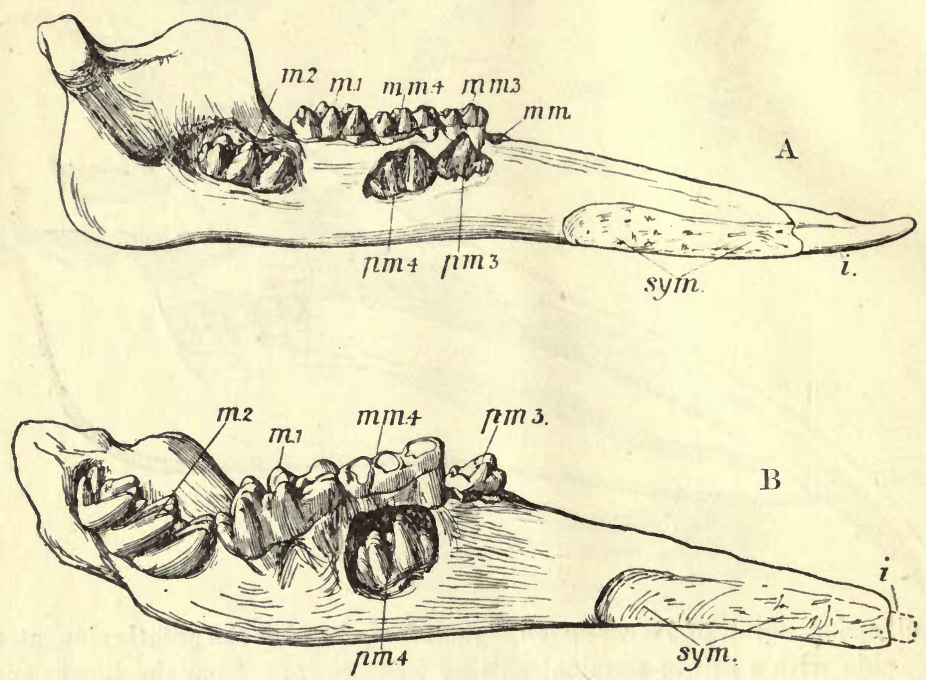

Lower milk-dentition of (A) Palcomastodon, (B) Tetrabelodon angustidens. Showing some of the milk-teeth in situ, with the germs of replacing premolars. The germs of the 2nd molars are shown at the back of the jaw. About $\frac{1}{5}$ nat. size.

i., incisor; m. 1-2, permanent molars; m.m. 3-4, third and fourth milk-molars; m.m., socket of second milk-molar ; pm. 3-4, premolars ; sym., symphysis of mandible.

great changes have taken place. The milk-molars are still replaced by premolars, but these are quickly dropped out (fig. $13 \mathrm{~B}$ ). This is chiefly the result of the great increase in size of the true molars, particularly of the third, which is not accompanied by a corresponding increase in the length of the tooth-bearing portion of the jaws, so that there is not room for 
the premolars and molars to remain in position at the same time. The consequence of this is, that as the posterior molars are cut they move forward to take up their position in the jaw, thrusting out the teeth in front of them so that in the adult only the two large back molars remain on each side in both jaws, and in old individuals perhaps only the last is left. This mode of replacement is shown in fig. $13 \mathrm{~B}$. In this species, while the first and second molars still have only three ridges, as in Palcomastodon, the last may have five or six, and, as already mentioned, all are proportionately very large.

Fig. 14.

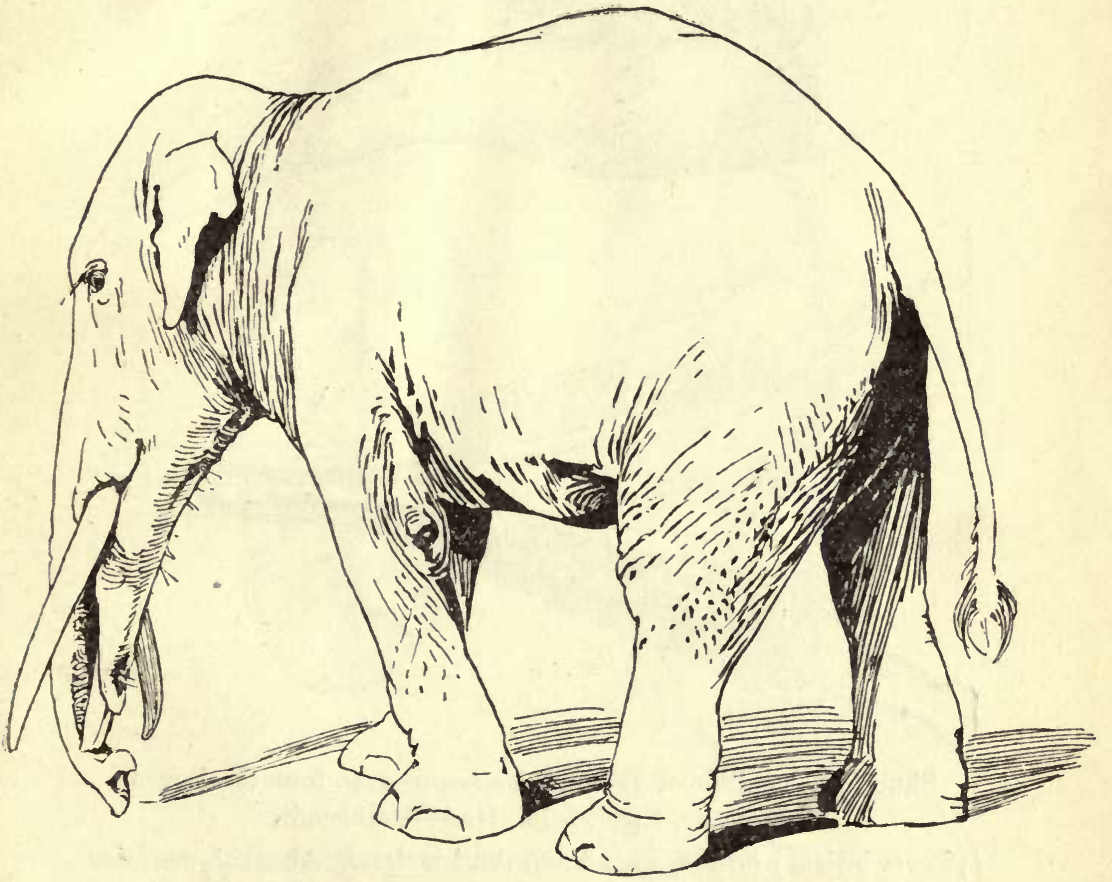

Restoration of Tetrabelocion angustidens.

In the mandible (fig. 12) the anterior portion is extremely long and projects much further beyond the skull than it does in Palcomastodon; and indeed it is in this species that we have the greatest degree of lengthening of the lower jaw. The two lower 
Pier- incisors, as in Palcomastodon, help to add to the length, and cases 41,42 . Tablewere no doubt used for grubbing in the earth. The remarks made about the upper cheek-teeth are equally true of the case 23. lower. The neck seems to have been a little longer and more

Fig. 15.

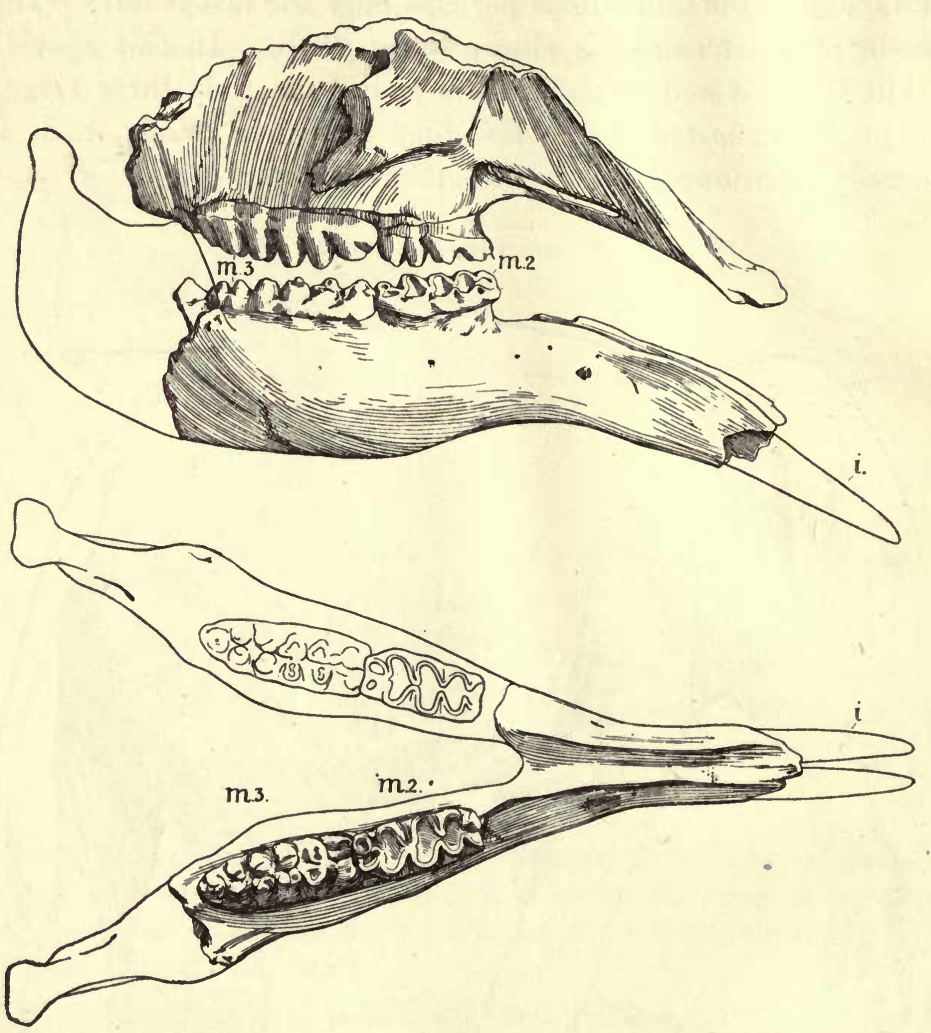

Skull and mandible of Tetrabelodon longirostris, from the Lower Pliocene, Eppelsheim, Hesse-Darmstadt. $i$, lower incisor; m. 2-3, second and third molars. About $\frac{1}{12}$ nat. size.

flexible than in the modern elephant, but the limbs and other parts were much the same. This animal when living (fig. 14) must have been still more like an elephant than Palaomastodon, and the most noticeable difference would be that here also, instead of the flexible trunk there was a long stiff 
snout which was supported by the elongated front of the lower jaw. Probably the end of the upper lip and nose was free and moveable, and may even have been able to grasp objects to some

Fig. 16.

Piercases 41,42 .

Tablecase 23.

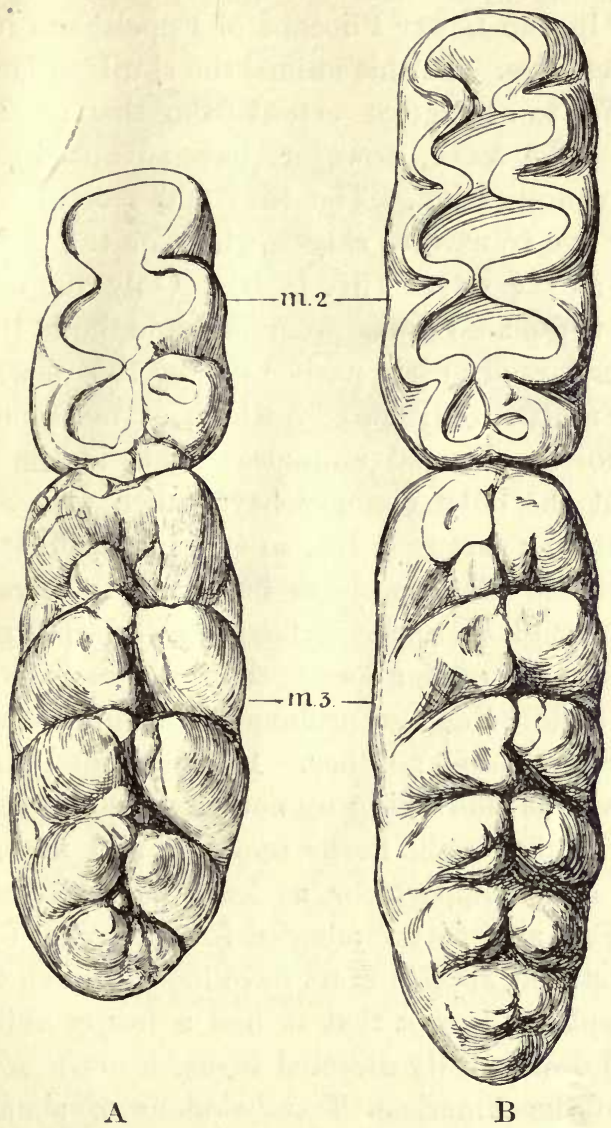

Second and third lower molars of (A) Tetrabelodon angustidens, and (B) Tetrabelodon longirostris. $\frac{1}{3}$ nat. size.

extent, but the whole arrangement seems to be rather clumsy. In most groups of animals as size increases the length of the neck becomes greater in proportion, so that the animal can still reach the ground; but in these early elephants, in spite of 
Pier- the great increase in size, the neck actually shortened, and it was

cases 41, 42 . Tablecase 23 . only this extraordinary lengthening of the snout that enabled the animals to reach to feed or drink.

The next stage in this strange history is found in Tetrabelodon longirostris (fig. 15), an elephant of which the remains are common in the Lower Pliocene of Eppelsheim in Germany and other localities. In this animal the skull, so far as known, does not differ to any great extent from that of Tetrabelodon angustidens. The teeth, however, have advanced considerably in size and complication. The first and second molars may have four or five transverse ridges, while in the last there may be as many as six ridges (fig. $16 \mathrm{~B}$ ). Only one of the milkmolars is now replaced by a premolar, and both this and the other milk-molars are early pushed ont by the forward growth of the large molars, only two of which at most on each side remain in position in old animals. It is in the lower jaw, however, that the chief changes have taken place. Here the elongated anterior part (fig. 15), so striking in the last type, has become shortened till it projects but little in advance of the skull, and although its upper surface is still deeply grooved and spout-like as in the earlier forms, the lower incisors no longer meet in the middle line and prolong the spout, but are rounded and separated from one another. In this animal it is clear that the lower jaw was shortening up and could no longer reach the ground, but doubtless the fleshy upper lip and nose, now freed from their bony support for at least part of their length, became flexible and better adapted for grasping the animal's food. In fact, this species must have looked much the same as a modern elephant, except that it had a longer chin bearing a pair of small downwardly directed tusks.

In some of the American Tetrabelodons of about the same age as $\boldsymbol{T}$. longirostris, the lower tusks, instead of undergoing reduction, seem to have become greatly enlarged, and at the same time the symphysial portion of the mandible is slightly deflected, so that the mandible with its tusks is to some degree similar to that of Dinotherium. An example of this form of jaw is seen in the case of the mandible of a Tetrabelodon, from the Loup Fork Beds (Upper Miocene) of Kansas, exhibited in pier-case 42. 
This species has, of course, no near relationship with Dinotherium (fig. 17), which forms a side branch of the Proboscidea, and is widely different from all the other members of the group. The earliest known member of the genus is Dinotherium cuvieri, a comparatively small animal, which is

Wallcase 43. Case C.

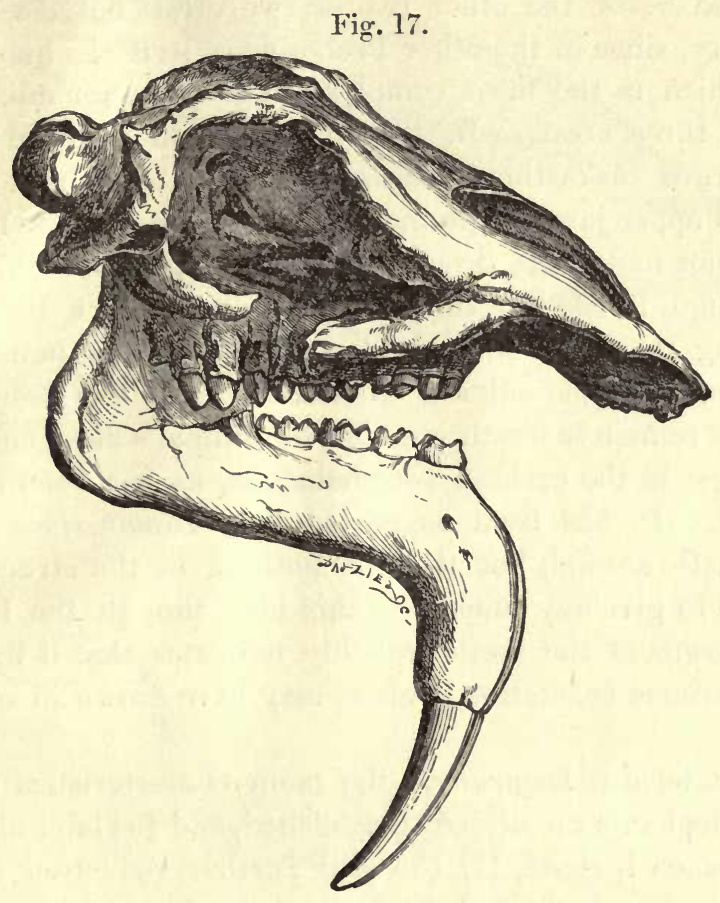

Skull of Dinotherium grganteum from the Lower Pliocene of Eppelsheim, Hesse-Darmstadt. $\frac{1}{15}$ nat. size.

found in the same deposits as the earliest known remains of Tetrabelodon angustidens, and, as in the case of that species its ancestors probably lived in Africa, though up to the present no traces of them have been discovered. In the later Miocene beds occur a number of species, some of enormous size (e. g. D. gigantissimum from Roumania). The genus finally disappears in Lower Pliocene times. The chief peculiarity of these animals is, that the front part of their lower jaw is turned sharply downward and bears two large tusks (fig. 17, 
Wall- case C.) ; it is not certain whether or not there were any tusks case 43. in the upper jaw. The teeth are of a much simpler character Case 6. than those found in the Mastodon-elephant line. In the upper jaw of the adult there are two premolars, both simpler than the molars; of these latter the anterior one consists of three transverse crests, the other two of two crests only, a notable peculiarity, since in the other Proboscidea it is the hindermost molar which is the most complex. The posterior milk-molar also has three crests. In the lower jaw in addition to the down-turned tusks there are two premolars and three molars. As in the upper jaw, the premolars are simpler than the molars: the anterior molar has three crests, the second and third two only, though in the last there may be a trace of a third. In the young there are three milk-teeth, the hinder one having three crests, like the anterior true molar. All the molars and premolars remain in use throughout the animal's life, a condition already lost in the earliest Tetrabelodons, as has been already described. It has been suggested that Dinotherium was a more aquatic animal, but there is nothing in the structure of the limbs to give any support to this idea, though the lowness of the crowns of the teeth probably indicates that it lived on soft herbaceous vegetation, such as may have grown in swampy places.

Pier- In Tetrabelodon longirostris the main characteristics of the cases $41,4 \div$ modern elephants are already established, and the later changes of importance include, (1) the still further reduction of the mandibular symphysis and the loss of the lower incisors, and (2) the great increase in the size and complication of the cheek-teeth. It will be convenient to consider these changes separately.

Pier- In the shortening of the chin the next stage is found in case 37. Pliocene forms like Mastodon atticus from the Lower Pliocene of Pikermi. In this the symphysis, "though much shortened, is still more or less spout-like, and in very young individuals the incisors may be present, though they are soon shed; the absence of these teeth in the adult is the chief character distinguishing the genus Mastodon (fig. 18) from Tetrabelodon. One of the best known species belonging to this stage of 
development is Mastodon arvernensis, which is found in Europe in Pliocene deposits ; in it the lower incisors seem to be entirely wanting, and the anterior molars have four transverse ridges.

Fig. 18.
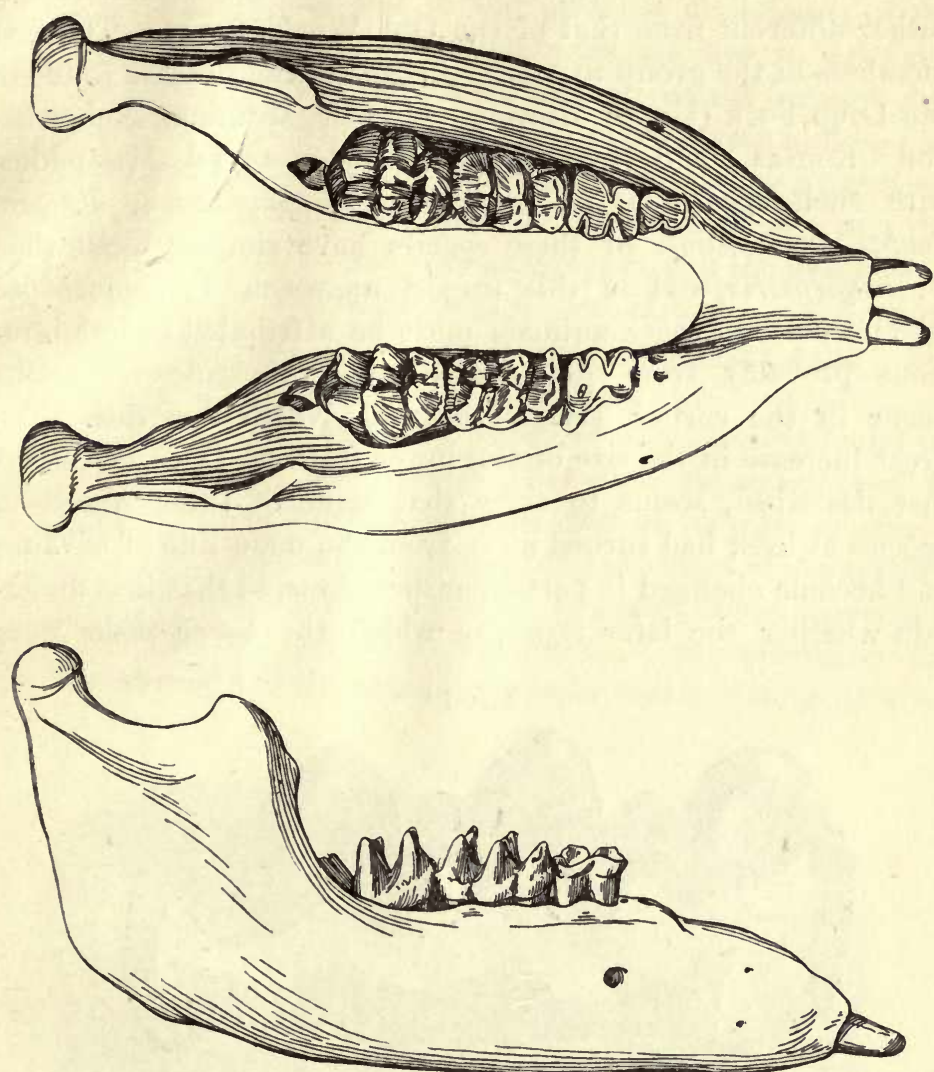

Mandible of a young individual of Mastodon americanus showing the small remnants of the lower incisors. In the adult these are lost. From a Pleistocene Deposit, North America. About $\frac{1}{7}$ nat. size.

A nearly allied species, $M$. sivalensis (fig. 20), from the Pliocene of India, is notable as showing a tendency to acquire five ridges to its molars.

The region in which the passage from the Mastodons to the true elephants occurred, seems to have been Southern Asia, 
Pier- where, in a succession of Pliocene and Pleistocene deposits,

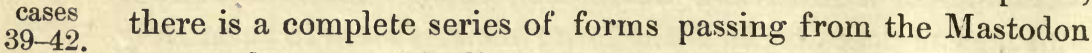
up to the recent Indian Elephant. How far these changes may have gone on in the rest of the Northern Hemisphere is not known, but the history of the Mastodons in America is rather different from that of the Old World forms. The first members of the group to appear in North America are found in the Loup Fork (Upper Miocene) beds of Montana, Nebraska, and Kansas, and include Tetrabelodonts and Mastodons, with such species as T. campestris, T. euhyphodon, T. productus, \&c. Some of these species have simpler teeth than $T$. longirostris, and in this respect approach $T$. angustidens. The presence of these animals must be attributed to immigrations probably from Asia, since no Proboscidean remains occur in the earlier Tertiary beds of North America. The great increase in the size of the lower teeth of $T$. (?) precursor, just described, seems to show that some of these American species at least had turned away from the main line of advance and become changed in particular directions, so that it is uncertain whether the later types, in which the lower tusks were

Fig. 19.

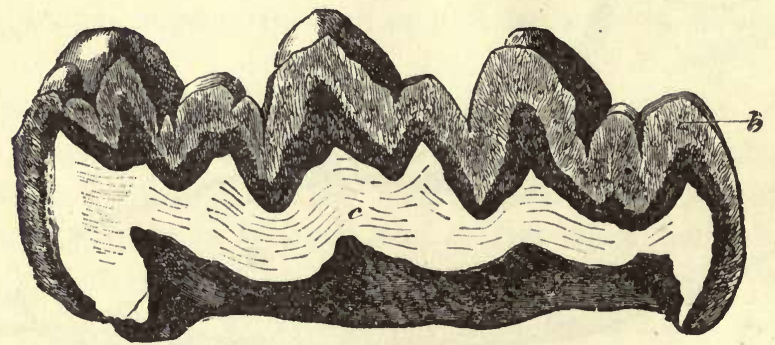

Vertical longitudinal section of a molar tooth of a Mastodon, showing the low crown, the open valleys between the cross-ridges and the thick enamel $(b)$. c., dentine. $\frac{2}{3}$ nat. size.

reduced and finally lost, are descendants of these or represent further invasions from outside. These later forms spread into South America, where several peculiar species are found which Stand B. persisted with little change till the Pleistocene. Probably the reason why these Mastodons, as well as M.americanus of North 
America, continued in a comparatively primitive condition, is to be found in their considerable isolation and freedom from competition. One South American species, M. andium, is particularly interesting on account of its variability, especially in the length of the chin and in the presence or absence of the lower tusks. Some of these differences are due to sex, and perhaps age, but the variations are no doubt mainly due to the fact that the symphysis and lower tusks were undergoing reduction and that the latter were about to disappear altogether. Neither in North nor in South America does it appear that the Mastodons gave rise to more advanced types, and the presence in the Pleistocene of North America of true elephants ( $E$. columbi and $E$. primigenius) is due to immigration from Asia. No species of Elephas reached South America.

To return to the series of stages of development found in Southern Asia, the first species that need be considered is Mastodon cautleyi, which in the character of its teeth is nearly related to Tetrabelodon longirostris, but the ridges of the molars are comparatively higher. There is, however, as yet no cement in the valleys (fig. 19), which are more or less obstructed by small tubercles, and the inner cusps wear into a trefoil pattern,

Fig. 20.

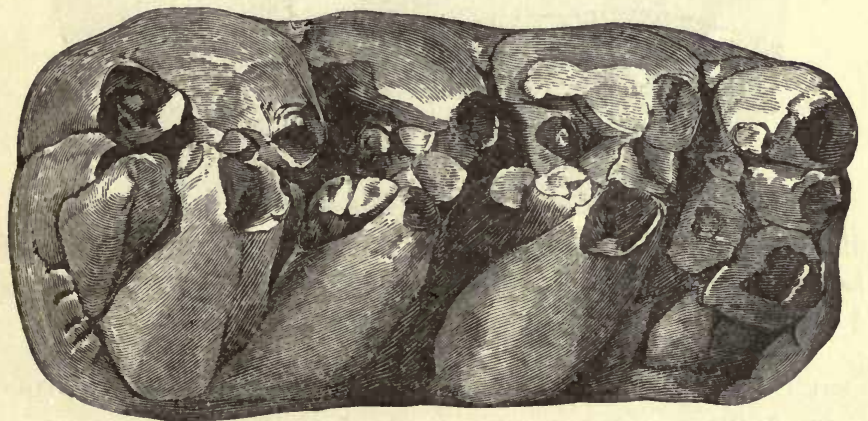

Grinding surface of a lower molar tooth of Mastıdon sivulensis. From the I,ower Pliocene of the Siwalik Hills, India. $\frac{2}{3}$ nat. size.

as in Tetrabelodon angustidens and $T$. longirostris. While, however, the anterior molars are almost identical with those of T. longirostris, the posterior lower molar is very similar to that 
of $M$. latidens, which in its turn approaches Elephas (Stegodon) clifti (fig. 21) very closely. In M. latidens there are as a rule five transverse ridges in the second upper molar and six in the last.

Pier- The next stage is represented by Elephas (Stegodon) clifti cases $35,36$. Tablecase 24. Stand J. (fig. 21). With this species we reach the true elephants, though the molars have much lower crowns and fewer transverse ridges than in the modern species of Elephas; and, in fact, these earlier forms are sometimes separated into another genus called Stegodon. . Since, however, no real line can be drawn between them and the later types it is perhaps best to call all Elephas, but distinguish these earlier forms by adding the name Stegodon in brackets as above. In all this group the lower incisors have entirely disappeared, the anterior elongation of the chin at

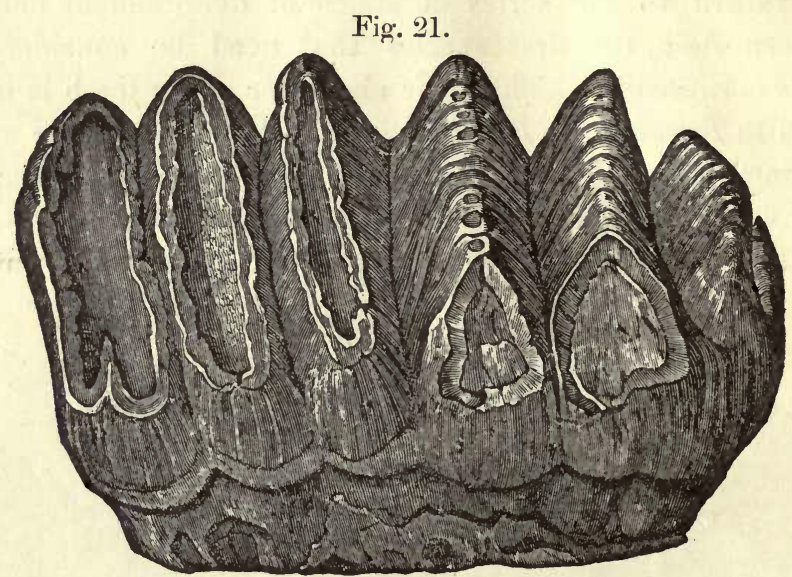

Grinding surface of an upper molar tooth of Elephas (Stegodon) clifti. From Lower Pliocene, Siwalik Hills, India. Showing six transverse ridges. $\frac{1}{2}$ nat. size.

the same time being reduced to a mere peg-like process (figs. $23 \& 30$ ), and a greater or less amount of cement (see above, p. 12) fills the transverse valleys in the crowns of the molars (fig. 22). In Elephas (Stegodon) clifti the number of ridges is greater than in Mastodon cautleyi. In order to express briefly the number of ridges in the molars of this and other species, a formula is used thus:-In $E$. clifti the formula 
M $1 \frac{6-7}{?}$, M $2 \frac{6}{?}$, M $3 \frac{7-8}{7-8}$, means that in the first true molar (M 1) there are in the upper jaw 6-7 ridges, while in this case the Piercases $35,36$. number in the lower is not known. In the second molar (M 2) there are 6 in the upper, the lower being uncertain, while in the last molar (M 3) there are 7-8 ridges in both the upper and Tablecase 24. lower jaw. It will be seen, therefore, that the numerator of the fractions represents the number of ridges in the upper teeth, the denominator the number in the lower. When the two numbers are given thus, 6-8, it means that the number of ridges varies between them. This formula will be employed below in describing the molars, and a table showing the gradual increase in the number of ridges will be given at the end.

In $E$. clifti premolars are still developed, but must have been pushed out almost as soon as the milk-molars they replace. The crowns of the molars are quite low, and there is only a small quantity of cement in the valleys betweer the ridges.

In Elephas (Stegodon) bombifrons and E. insignis (fig. 22), which represent the next stage, the transverse ridges are somewhat more numerous and at the same time are higher, and the

Fig. 22.

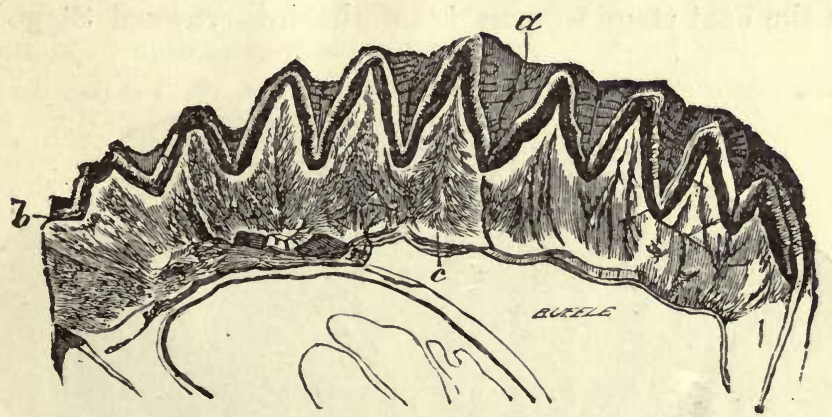

Vertical longitudinal section of molar tooth of Elephas (Stegodon) insignes.

From Lower Pliocene, Siwalik Hills, India. Showing the wide valleys between the cross-ridges filled with cement $(a)$, the dark band marked $b$ being the enamel, and beneath that the dentine $(c)$. $\frac{1}{3}$ nat. size.

valleys are filled with cement to a greater degree. Nevertheless these- differences are not very marked, and in the case of individual teeth it is often difficult to be sure to which of these 
Stand J. species they belong. In some of the Stegodont elephants the tusks attain an enormous size; for instance, in a skull of

Fig. 23.

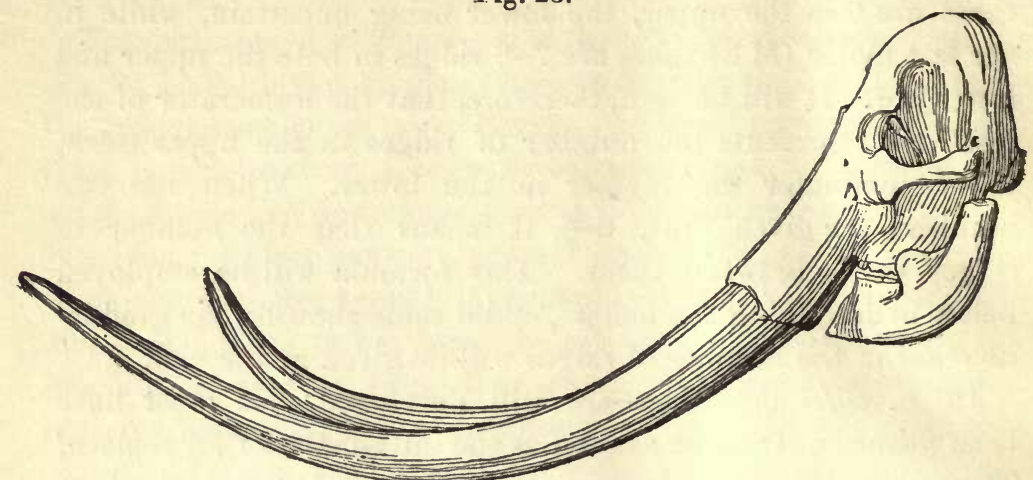

Skull and mandible of Elephas ganesa, showing the immense upper tusks and the shortened chin. From Lower Pliocene, Siwalik Hills, India. Abuut $\frac{1}{32}$ nat. size.

Elephas (Stegodon) ganesa (fig. 23), exhibited in the gallery (stand J), the tusks project for a distance of $9 \mathrm{ft} .9 \mathrm{in}$. beyond the sockets.

Pier- In the next stage we pass from the low-crowned Stegodont case 34 . Fig. 24.

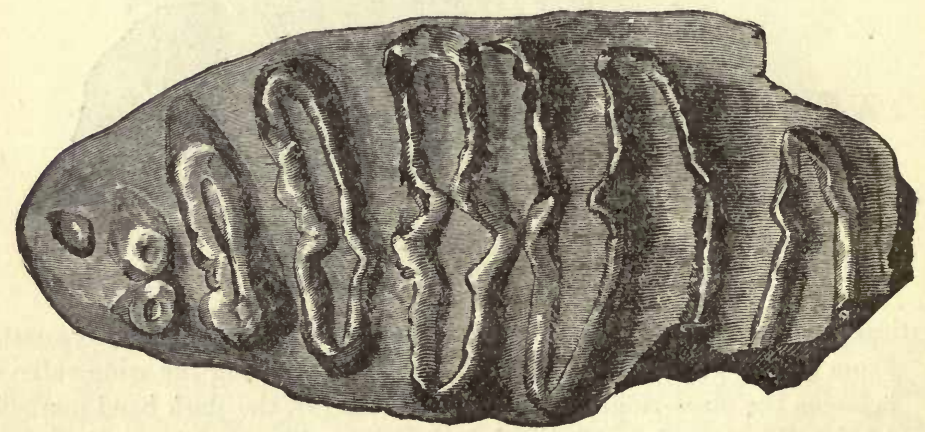

Grinding surface of an incomplete upper molar of Elephas planifrons.

From Lower Pliocene, Siwalik Hills, India. $\frac{2}{3}$ nat. size.

group to animals in which the ridges are considerably higher and the valleys completely filled with cement; this is called the Loxodont group. The most primitive member is Elephas 
planifrons (figs. 24 \& 25), in which the posterior molars may have as many as twelve ridges. This is the last of the elephants in which premolars have been observed; these teeth are small and

Piercase 34 . Tablecase 24 .

Fig. 25 .

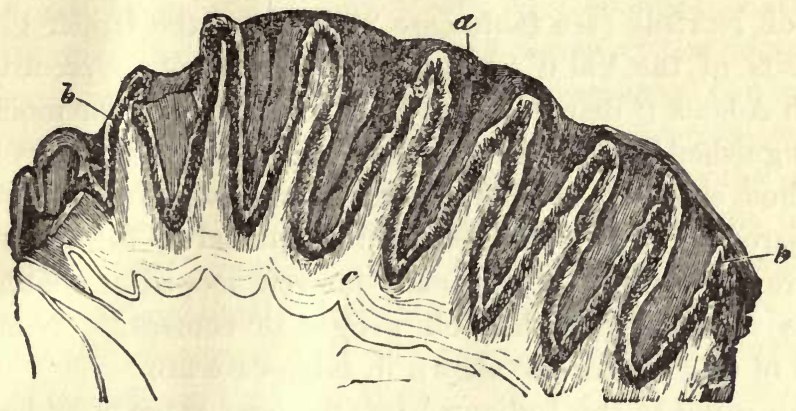

Vertical longitudinal section of molar tooth of Elephas planifrons, showing the deeper and narrower valleys completely filled with cement $(a)$. The enamel layer is marked $b$, the dentine $c$. $\frac{1}{3}$ nat. size.

closely crowded up beneath the milk-molars, so that when those teeth are greatly worn the premolars are exposed to view, and are no doubt shed as soon as, or even before, the posterior part of the milk-molars they should replace.

'The species $\boldsymbol{E}$. meridionalis (fig. 26), of which remains are

Fig. 26.

Piercase 33.

Table-

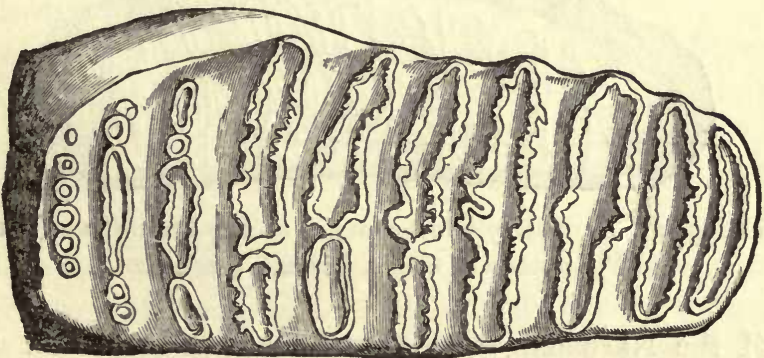

case 20 .

Grinding surface of upper molar of Elephas meridionalis. Upper Pliocene, Tuscany. About $\frac{1}{3}$ nat. size.

found in the Pliocene of Middle and South Europe, seems to be closely related to $E$. planifrons, and is in about the same stage of 
Pier- evolution, or perhaps a little more advanced. The last molars case 33. may have 13-14 ridges, and in some cases approach the condition Tablecase 20.

Piercase 33. seen in $\boldsymbol{E}$. hysudricus. E. meridionalis attained enormous dimensions, some individuals probably standing about 15 feet in height at the shoulder. Remains of this species occur in the Forest Bed of Norfolk (see table-case 20) and in the Upper Pliocene deposits of the Val d'Arno and the Auvergne. According to Leith Adams ('British Fossil Elephants,'p. 232) the molars are distinguished by the following characters :- "Crowns very broad; columns short as compared with $E$. antiquus, and generally as compared with $E$. primigenius; the enamel of the discs thick and rarely crimped, but usually uneven, looped or channelled; plates wide apart, with thick wedges of cement." Numerous teeth of this species are shown in table-case 20 .

Returning to the Indian series, the next stage may be taken as represented by Elephas hysudricus, in which there is a considerable increase in the height of the teeth and in the number of the ridges. The skull is in many respects similar to that of $\boldsymbol{E}$. maximus, the modern Indian elephant, which may have been its direct descendant. E.hysudricus, like E. meridionalis, sometimes attained a very large size. This species occurs at the end of the Pliocene and perhaps in the early Pleistocene

Fig. 27.

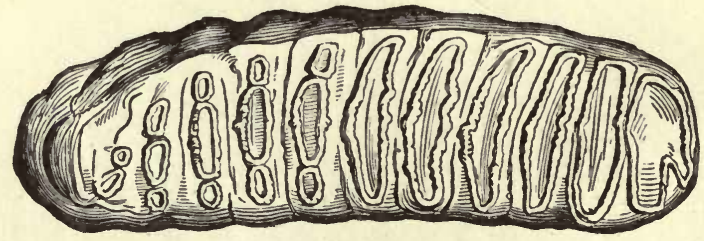

Grinding surface of second lower molar of Elephas antiquus from the Pleistocene of Grays, Essex. $\frac{1}{3}$ nat, size.

Pier- beds of the Narbada. Contemporary with it was $E$. antiquus case 33. (fig. 27), a large elephant found in the late Pliocene and early Table- Pleistocene of Europe, and appearing in beds of the latter
cases 19,19A. horizon of India, where it has been called $E$. namadicus. In this species the skull is peculiar from the development of a 
sort of overfolded ridge on its frontal portion, forming an overhanging fold on the forehead (see pier-case 34). The presence of this peculiarity makes it very unlikely that any of the later forms in which it is absent were descended from this species, which is of particular interest because it was very widely distributed. In the changes that took place in the distribution of land and water at the end of the Pliocene and the beginning of the Pleistocene, poritions of the regions inhabited by this form and its varieties became isolated as islands, and in these restricted habitats the species became dwarfed and the dwarf forms in the different islauds at the same time became specifically distinct from one another. Instances of these small forms are Elephas melitensis, E. mnaidriensis, E. cypriotes, and E. creticus. $E$. melitensis and E. mnaidriensis are found in Malta. Of the first-named species a small form sometimes called $E$. falconeri did not stand more than about three feet high at the shoulder. The ridge-formula of the molar teeth is :- $\mathrm{M} 1 \frac{8-9}{8-9}, \mathrm{M} 2 \frac{10}{10}, \mathrm{M} 3 \frac{12-13}{12-13}$. A large collection of remains of these species, obtained by Admiral Spratt and Professor Iseith Adams, is shown in table-cases 21 \& 21 A. E. mnaidriensis is also found in Sicily ; probably this species, which is larger than E. melitensis, represents the intermediate stage between it and $E$. antiquus. E. cypriotes from Cyprus, and $E$. creticus from Crete, were both discovered and described by Miss D. M. A. Bate, who collected the specimens shown in table-case $17 \mathrm{~A}$.

Turning again to the main line, we find that Elephas hysudricus probably passed into some such species as E.armeniacus, which in many respects is intermediate between the Mammoth (E. primigenius) and the living Indian Elephant (E. maximus). The Mammoth seems to represent the highest pitch of evolution attained in the Elephantidæ, being in some respects in advance even of the Indian Elephant. It is here that we meet with the greatest number of ridges in the molars (fig. 28), the formula being $\mathrm{M} 1_{9-15}^{9-15}, \mathrm{M} 2_{14-16}^{14-16}, \mathrm{M} 3_{18-27}^{18-27}$. These teeth represent the culmination of the long series of changes above described, all tending to increase the efficiency of the molars

Tablecase 17.
Piercase 34.

Tablecases $17 \mathrm{~A}$, $21,2] \mathbf{A}$. 
Piercases $30-32$.

Tablecases 17-19.

as grinding organs. The great size, and especially height, of the crown gives them a prolonged period of wear, while the numerous alternating plates of enamel, dentine, and cement, of different degrees of hardness, ensure that the grinding

Fig. 28.

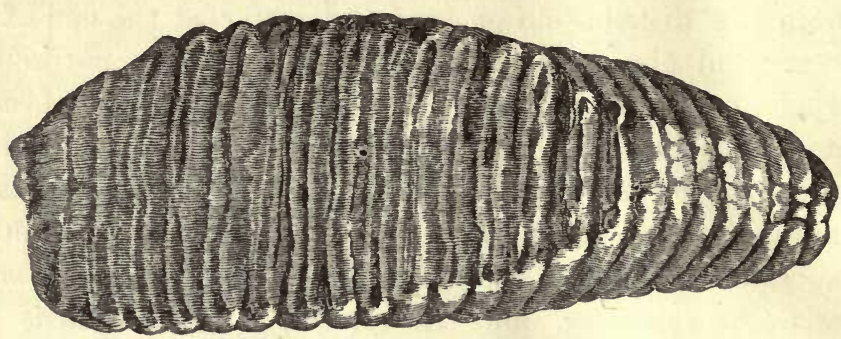

Grinding surface of molar tcoth of the Mammoth (Elephas primigenius), showing some still unworn posterior plates. About $\frac{1}{4}$ nat. size.

surface will remain sufficiently rough for its purpose throughout the period during which the tooth remains in use. The Mammoth was a very widely-distributed form, being found all over Northern Europe, Asia, and America, and it seems to have been particularly abundant in 'Siberia and the islands to the north, where remains occur in great abundance, and whence the tusks are actually exported for commercial purposes. The extinction of the Mammoth appears to have been a comparatively recent event, and in Siberia portions of carcases with the skin and flesh in good preservation are found in the frozen tundras. An instance of this kind is illustrated by drawings and photographs on the pillar between pier-cases 31-32. In this instance the animal seems to have fallen into a hole and to have died in its efforts to scramble out. The mouth was found still filled with the grass on which the animal was browsing at the time when it met with the accident. This individual, restored and mounted in the attitude in which it was found, is now exhibited in the Imperial Academy of Sciences at St. Petersburg. This specimen, with many others, shows that the Mammoth was covered with a reddish-brown wool and long dark hair, while the tail ended in a large tassel of hair. A 
piece of the skin with its woolly covering and some of the long hair are shown in pier-case 31. Further confirmation of this Pierpeculiarity of the Mammoth is found in the rude sketches scratched on ivory by early Man, who was evidently quite faniliar with the animal. A reproduction of one of these early drawings is shown near wall-case 1 .

The finest Mammoth skull hitherto collected in England Case К. is shown in case $\mathrm{K}$ : this specimen was obtained from the brickearth at Ilford in Essex. Most of the skeleton seems to have been found with it, but the bones were unfortunately destroyed before their interest was recognised. The tusks in this skull are 10 feet 6 inches in length beyond the sockets.

Fig. 29.

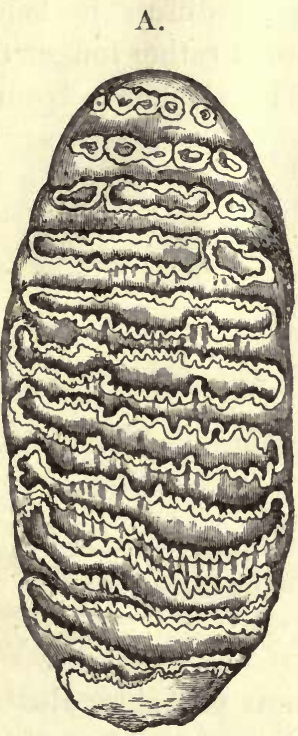

B.

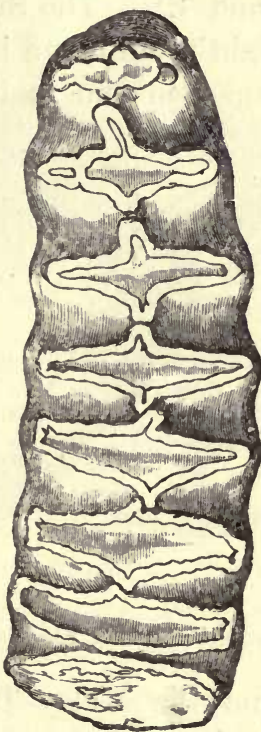

Grinding surface of upper molars of (A) the Asiatic, and (B) the African Elephant. About $\frac{1}{3}$ nat. size.

The Indian elephant, E. maximus (fig. $29 \mathrm{~A}$ ), one of the two Stands surviving species of the suborder, is found in India, Ceylon, D, E. and the Malay Peninsula to Sumatra. The chief peculiarities of the species, distinguishing it from the African elephant, are 
Stands the flatness of the forehead, the comparatively small ears, the D, E. presence of a single finger-like process at the front of the end of the trunk (fig. $31 \mathrm{~A}$ ), and the presence of four or five nails on the hind feet. As might be expected from the wide range of this species, different local forms can be distinguished, and in some cases these have even been regarded as specifically distinct, as, for instance, the elephant of Sumatra, which has been called $E$. sumatranus. It seems, however, that all are merely geographical races of the same animal. The Ceylon form is said to be as a rule tuskless, and although tuskbearing forms do occur in the island, they may be either animals imported from the mainland of India or the result of former interbreeding with such. In India, also, some individuals, called Muchnas, are tuskless or have very small tusks (see mounted skin, stand E). The Sumatran type differs in being rather more slightly built, and in possessing a rather longer trunk and more expanded end to its tail. The elephants from Further

Fig. 30 .

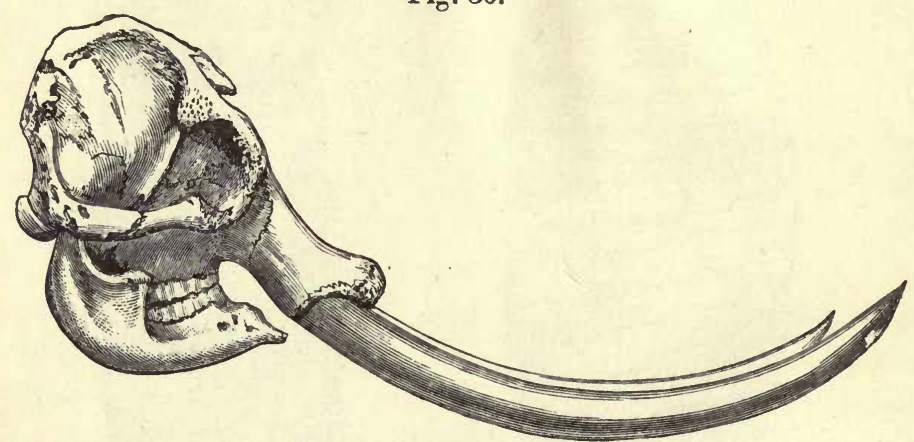

Skull of the African Elephant (Elephas africamus). About $\frac{1}{28}$ nat. size.

India and the Malay Peninsula are probably also a distinct race which seems especially liable to produce albino forms, the white elephants of Siam and Burma being well known.

The origin of the other living species of elephant, Elephas africanus (fig. 30), is not very clearly known, owing to the want of fossil remains in the later Tertiary beds of Africa. It appears probable that the narrow-toothed, straight-tusked form of $E$. antiquus was either the ancestor, or nearly allied to the 
ancestor, of the African Elephant, a conclusion that is supported by the recent discovery in Zululand, in beds of probably late Pliocene age, of a molar which is very similar to some molars of $E$. antiquus. This Zululand species has been called Elephas zulu, and was found associated with remains of other mammals, the first Tertiary mammalian fauna hitherto discovered in South Africa. .

The African Elephant to-day ranges very widely over Africa south of the Sahara, but fossil remains have been found in Central Hall. Northern Africa and in the south of Europe. It is distinguished by its convex forehead, its very large ears, and by the presence of two finger-like processes on the tip of the trunk (see fig. $31 \mathrm{~B}$ ). The molar teeth are considerably simpler than those of the Indian species (see fig. $29 \mathrm{~B}$ ), the ridges being

Fig. 31.

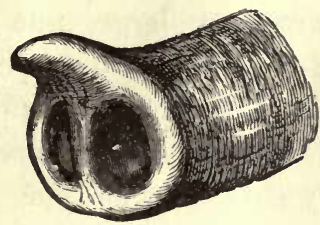

A

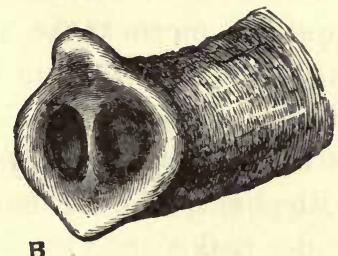

B

Tip of trunk of (A) the Asiatic and (B) the African Elephant.

fewer in number and widening out in the middle in a peculiar manner; the teeth also are relatively smaller than in other elephants. In fact if, as is almost certain, $E$. africanus is derived from some such species as $E$. antiquus or $E$. $z u l u$, then the changes that the molars have undergone are not in the same direction as those which gave rise to the Indian Elephant and the Mammoth, but are to some extent retrograde.

It has lately been shown that although there is only a single species of African Elephant, nevertheless, in different parts of the continent, there are different local races which may perhaps be regarded as subspecies, and are in fact species in the making. Differences in the form of the skull of these different races can be detected, but the most striking characters distinguishing them from one another are the size and shape of the ears. 
Central According to Mr. Lydekker the distinctive features of these Hall. local races are :-

I. In the Addo Bush, or East Cape, Elephant (Elephas africanus capensis) the ears are rather small, somewhat square in shape, with rounded corners, and a small, sharply pointed angular lappet at the lower angle. The forehead falls away towards the temples, so as to appear highly arched.

II. The West Cape Elephant (E. a. toxotis) has the ears much larger ( $4 \mathrm{ft} .5$ in. in a female $8 \mathrm{ft} .8 \mathrm{in}$. high), longer, and semi-oval in shape; although, as in the preceding race, sharply inflected at the lappet.

III. In the Matabeleland race (E. a. selousi) the ear is much less elliptical than in the West Cape Elephant, and approaches more to that of the Camerun race, but agrees with that of the former in that the lappet underhangs the jaw and chin.

IV. In the West African Elephant (E. a. cyclotis), typically from South Cameruns, the ears are very large, but of quite different shape, the contour being oval, and the lappet in the form of half-ellipse. The skin has a mosaic-like appearance, and its colour is paler grey than in most other races. The Congo Elephant, which comes very close to this type, has long and slender tusks.

V. The Masai Elephant (E. a knochenhaueri), typically from German East Africa, has small triangular ears, with the lappet angulated and pointed. The exhibited specimen (which stands $11 \mathrm{ft} .4$ in. in height, with ears measuring $4 \mathrm{ft}$. $2 \frac{1}{2} \mathrm{in}$. by $3 \mathrm{ft}$. 5 in.) may belong to this race.

VI. In the Aberdare Elephant (E. a. peeli), typically from the Aberdare Mountains, British East Africa, the ears are pearshaped, with the lappet very long, although somewhat rounded at the tip.

VII. The Lake Rudolf Elephant (E. a. cavendistii) is nearly allied to the last, but has broader ears, in which the lappet is shorter.

VIII. In the Abyssinian, or Sudan, Elephant (E. a. oxyotis) the ears form an elongated triangle, with the upper border rounded and the lappet very sharply pointed and angular. This elephant attains very large dimensions. 
IX. The N. Somali Elcphant (E. a. orleansi), on the other Central hand, is small, with the upper border of the small ears straight, Hall. and the lappet short and distinctly defined.

X. In the West Sudan Elephant (E.a. rothschildi) the ears are in some respects intermediate between those of the Abyssinian and those of the West African race, although approximating to the former in the shape of the lappet.

There is also a dwarf elephant from the Congo (E. a.pumilio). The Albert Nyanza Elephant has been separated as E.a.albertensis, and is characterised by the unusually short and broad skull.

\section{RELATIONSHIPS OF THE PROBOSCIDEA.}

The discovery of the Eocene Proboscidea proves that, although the elephants are no doubt rightly included among the Ungulata or hoofed-animals, they are at the same time very widely separated from the other members of that group, or at least from the existing members of it, and seem to have formed an independent series from the earliest Tertiary times, when they probably arose from some quite generalised form of the primitive group called the Condylarthra. A very early side-branch from the Proboscidean stem is probably represented by the Sirenia or Sea-cows, aquatic animals which, though now as unlike elephants as possible, still possess a number of anatomical peculiarities in common with them, so that this relationship was recognised long ago. Recently a number of Sirenians have been found in the Eocene strata of Egypt (pier-case 30), one in the same horizon as Moeritherium. These early Sirenians are much less specialised than the existing forms, having the full series of teeth and a complete pelvis, and probably a functional hind limb. In many points they resemble Moeritherium, as for instance in the form of the brain, teeth, and pelvis; and it seems likely that both they and Moeritherium had a common ancestor in Lower Eocene times. It was probably a swamp-living creature, some of whose descendants became gradually more and more exclusirely aquatic in their habits, thus giving rise to the Sirenia, while others became

Piercase 30. 
exclusively terrestrial and gave rise to the elephants as described above.

TABLE SHOWING THE RIDGE-FORMULA OF THE TRUE MOLARS IN THF APPROXIMATE LINE OF DESCENT OF THE ElEphaNTS FROM Moeritherium.

\section{1. M 2. MI 3.}

\begin{tabular}{|c|c|c|c|c|}
\hline Moeritherium & 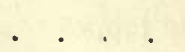 & $\frac{2}{2}$ & $\frac{2}{2}$ & $\underline{2}$ \\
\hline Palcomastodon & 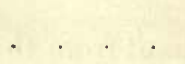 & $\frac{3}{3}$ & $\begin{array}{l}2 \\
\frac{3}{3}\end{array}$ & $\begin{array}{l}3 \\
3 \\
3\end{array}$ \\
\hline Tetrabelodon angust & tidens & $\begin{array}{l}3 \\
3\end{array}$ & $\frac{3}{3}$ & $\frac{4-5}{4-5}$ \\
\hline longiro & ostris & $\frac{4}{4}$ & $\begin{array}{l}4 \\
4\end{array}$ & $\frac{5-6}{5-6}$ \\
\hline Mastodon cautleyi & & $\frac{4}{4}$ & $\begin{array}{l}4 \\
4\end{array}$ & $\frac{5}{5}$ \\
\hline latidens & . & $\frac{4}{4}$ & $\frac{4-5}{4-5}$ & $\frac{5-6}{5-6}$ \\
\hline Elephas (Stegodon) & clifti . & $\stackrel{6-7}{?}$ & $\frac{6}{?}$ & $\begin{array}{l}7-8 \\
7=8\end{array}$ \\
\hline " & bombifrons & $\frac{6}{7}$ & $\begin{array}{l}6=7 \\
7=8\end{array}$ & $\frac{8-9}{8-9}$ \\
\hline " & insignis & $\frac{7-8}{7-10}$ & $\frac{7-8}{8-12}$ & $\frac{9-11}{9-13}$ \\
\hline Elephas planifrons & & 7 & $8-9$ & $\begin{array}{l}10-12 \\
10-13\end{array}$ \\
\hline hysudricus & 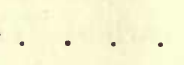 & $\frac{9-12}{9-12}$ & $\begin{array}{l}10-12 \\
12-13\end{array}$ & $\frac{13-17}{14-18}$ \\
\hline indicus. & ${ }^{\circ}$ & $\begin{array}{l}12 \\
12\end{array}$ & $\frac{16}{16}$ & $\frac{24}{24-27}$ \\
\hline , primigenius. & s. . & $\begin{array}{l}9-15 \\
9-15\end{array}$ & $\frac{14-16}{14-16}$ & $\frac{18-27}{18-27}$ \\
\hline
\end{tabular}

A series of specimens illustrating the gradual increase in the number of ridges on the molars is shown in table-case 24 . 
(The Guide-bools can be obtained only at the Museum. Postage extra.)

General Guide to the Museum, 8vo. 3d.

Guide to the Galleries of Mammals, 8ro. $6 d$.

Great Game Animals, 8ro. 1s.

Horse Family, 8vo. $1 s$.

Elephants (Recent and Fossil), 8vo. $6 d$.

Gallery of Birds, 4 to. $2 s .6 d$.

General Series of Birds, 4 to. $6 d$.

Nesting Series of British Birds, 4to. $4 d$.

Gallery of Reptilia and Amphibia, 8vo. $6 d$.

Gallery of Fishes, 8vo. 1s.

Exhibited Series of Insects, 8vo. 1s.

Shell and Starfish Galleries, 8ro. $6 d$.

Coral Gallery, 8vo. $1 s$.

Fossil Mammals and Birds, 8vo. $6 d$.

- Fossil Reptiles and Fishes, 8ro. $6 d$.

- Fossil Invertebrate Animals, 8vo. $1 s$.

Mineral Gallery, 8ro. 1d.

Index to the Collection of Minerals, 8 vo. $2 d$.

An Introduction to the Study of Minerals, with a Guide to the Mineral

Gallery, 8ro. $6 d$. to the Study of Rocks, 8vo. $6 d$.

to the Study of Meteorites, 8vo. $6 d$.

Guide to Sowerby's Models of British Fungi, 8vo. $4 d$. the British Myceto\%oa, 8vo. 3d.

List of British Seed-plants and Ferns, 8ro. $4 d$.

Special Guides: No. 1. Old Natural History Books, 8vo. $3 d$.

No. 2. History of Plant Classification, 8vo. $4 d$.

No. 3. Memorials of Linnæus, 8vo. 3d.

Handbook of Instructions for Collectors, 8vo. 1s. 6d.; or in eleven separate sections, at $3 d$. or $4 d$. each.

\section{CATALOGUES (Selection).}

History of the Collections:-Vol. I. Libraries; Botany; Geology; Minerals. 19G4, 8ro. 15s.-Vol. II. Zoology. 1906, 8ro. £1 10s. Catalogue of the Library of the British Museum (Natural History). Vols. I., II. 1903-4, 4to. £1 each.

lieport on the Zoological Collections made .... during the Voyage of H.M.S. 'Alert,' 1881-82. 54 Plates. 1884, 8ro. £1 10s.

Report on the Collections of Natural History made in the Antarctic Regions during the Voyage of the 'Southern Cross.' 53 Plates. 1902 , roy. 8 vo. $£ 2$.

Reports on the Natural History of the 'Discovery' National Antarctic Expedition, 1901-1904:- Vol. I. Geology. 10 Plates, 72 Textfigures, 2 Maps. 1907, 4to. £1 10s.-Vol. II. Zoology (Vertebrata : Mollusca: Crustacea). 33 Plates, 146 Text-figs. 1 Map. 1907,4to. £3. Vol. III. Zoology (Invertebrata) and Botany (Marine Algæ: Musci). 51 Plates, 8 Text-figures, 1 Chart. 1907, 4to. £2 10s.

Monograph of Christmas Island (Indian Ocean). Woodcuts, 22 Plates, and a Map. 1900,8 vo. $£ 1$.

First and Second Reports on Economic Zoology. Text illust. 1903-4. roy. 8vo. 6s. each.

Catalogue of Monkeys, Lemurs, and Fruit-eating Bats. Woodcuts. $18: 0,8$ vo. $4 s$.

Carnivorous Mammalia. Woodcuts. 1869, 8vo. 8s.6d.

- Seals and Whales. 2nd edition. Woodcuts. 1866,8 ro. $8 s$. Supplement. Woodcuts. 1871, 8vo. 2s. $6 d$. List of the Specimens of Cetacea. 1885, 8vo. 1s. $6 d$.

Catalogue of Ruminant Mammalia (Pecora). 4 Plates. 1872,8 vo. 3s. $6 d$. 


\section{CATALOGUES (Selection continued).}

Catalogue of Marsupialia and Monotremata. 28 Plates. 1888, 8vo. £18s. Birds. Vols. VII.-XXVII. Woodcuts and Coloured Plates. $1883-98,8$ vo. $14 s$. to $36 s$. a volume.

Hand-list of the Genera and Species of Birds. Vols. I.-IV. 18991903, 8vo. 10s. a volume.

Catalogue of Birds' Eggs. Vols. I-IV. Coloured Plates. 1901-5, 8 ro. $£ 15 s$. to $£ 110 s$. a volume.

Chelonians. Woodcuts and Plates. 1889, 8vo. 158.

Lizards. 2nd edition. Vols. I.-III. Plates. 1885-87, 8 vo. $20 s$. to $26 s$. each.

Snakes. Vols. I.-III. Woodcuts and Plates. 1893-96, 8 vo. $17 s$. $6 \mathrm{~d}$. to $£ 16 s$. each.

Fishes, 2nd edition. Vol. I. Woodeuts and 15 Plates. 1895, 8vo. 15 s.

Catalogue of British Echinoderms. Woodcuts and Plates. 1892, 8vo. $12 s .6 d$.

Madreporarian Corals. Vols. I.-VI. Plates. 1893-1906, 4to. 18s. to 35s. a volume.

Illustrations of Australian Plants collected in 1770 during Captain Cook's Voyage round the World in H.M.S. 'Endeavour.' Part I. 101 Plates. 1900, fol. £L 5s.-Part II. 142 Plates. 1901, fol. $£ 1$ 15s.-Part III. 77 Plates and 3 Maps. 1905, fol. £1 5s.

Catalogue of African Plants collected by Dr. F. Welwitsch in 1853-61 :Vol. I. 4 Parts, 1896-1900, 8vo. 4s. to 7s. 6d. each.-Vol. II. 2 Parts, 1899-1901, 8ro. 6s. each.

Catalogue of Fossil Mammalia. Parts I.-V. Woodcuts. 1885-87, 8 vo. 4s. to $6 s$. a volume.

Fossil Birds. 75 Woodeuts. 1891, 8vo. 10s. 6 d.

Fossil Rentilia and Amphibia. Parts I.-IV. Woodcuts. 1888-90, 8vo. Ts. $6 d$. a volume.

Fossil Fishes. Parts I.-IV. Woodcuts and Plates. 1889-1901, 8vo. 21s. a volume.

Catalogue of the Tertiary Vertebrata of the Fajûm, Egypt. 98 Textfigures and 26 Plates. 1906, 4to. £1 15s.

List of British Oligocene and Eocere Mollusca. 1891, 8ro. $6 s$.

Catalogue of Australasian Tertiary Mollusca. 8 Plates. 1897, 8vo. 10s. Catalogue of Fossil Cephalopoda. Woodcuts. Part I. 1888, 8ro. 10s. 6d. Part II. 1891, 8vo. 15s. Part III. 1897, 8vo. 12s.6d. 10sitish Fossil Crustacea. 1877, 8vo. 5s.

1896, 8vo. 16s.

Catalogue of the Cretaceous Bryozoa. Vol. I. 64 Woodeuts and 17 Plates. 1899, 8vo. 16s.

Blastoidea. 20 Plates. 1886, 4to. $25 s$.

The Genera and Species of Blastoidea. 1899, 8vo. 3s.

Catalogue of Palæozoic Plants. 1886, 8vo. 5s.

Mesozoic Plants. Woodcuts and Plates. 8ro.:-

The Wealden Flora. Part I., 1894, 10s. Part II., 1895, $15 s$.

The Jurassic Flora. Part I., 1900, 20s. Part II., 1904, 10s.

Catalogue of the Fossil Plants of the Glossopteris Flora. 51 Textfigures and 8 Plates. 1905, 8vo. 12s. 6d.

The abore-mentioned Catalogues may be purchased of Messrs. Longmans \& Co., 39 Paternoster Row ; Mr. Quaritch, 11 Grafton Street, New Bond Street; and Messrs. Dulau \& Co., 37 Soho Square; or at the Natural History Museum, Cromwell Ruad, London, S.W. A more detailed list may be obtained on application to the Director of the Museum. 


\section{DAY USE \\ RETURN TO DESK FROM WHICH BORROWED}

EARTH SCIENCES LIBRARY

This book is due on the last date stamped below, or

on the date to which renewed.

Renewed books are subject to immediate recall.

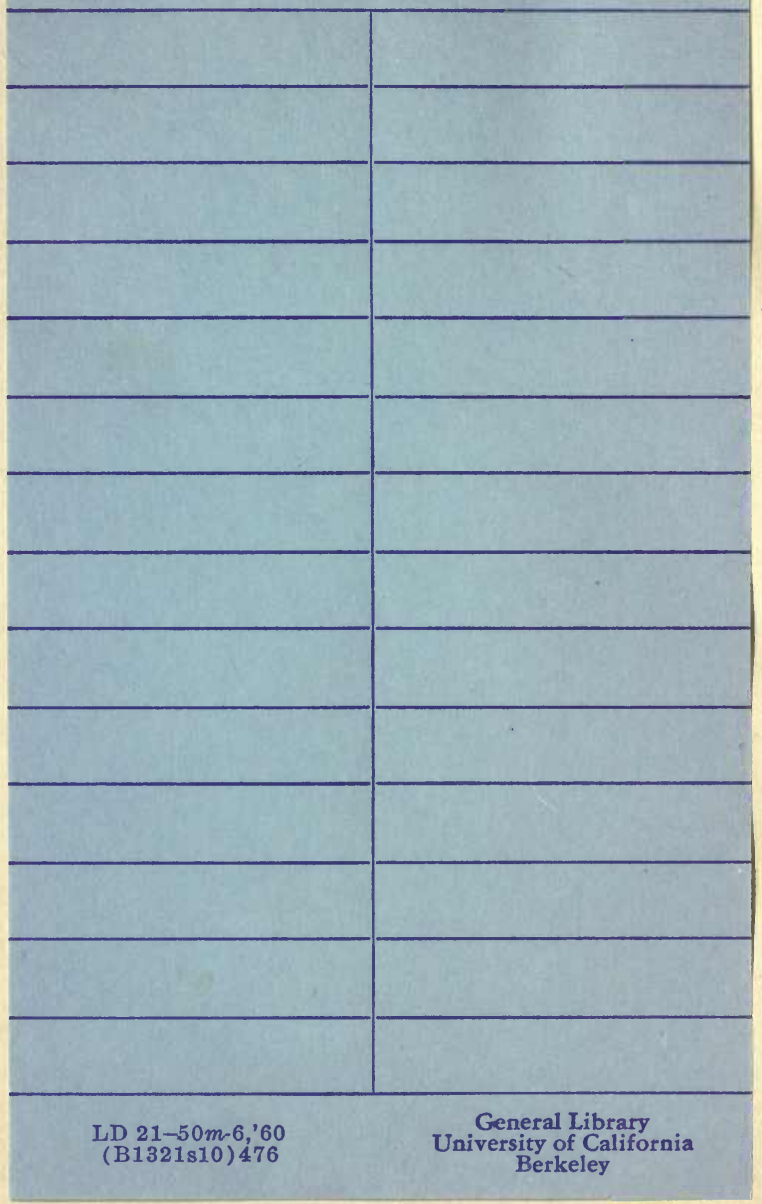


861 


\section{BRITISH MUSEUM (NATURAL HISTORY),}

\section{DAYS AND HOURS OF ADMISSION.}

The Exhibition Galleries are open to the Public, free, every weekday in

January, from 10 A.M. till 4 P.s.

Fobruary lst to 14 th, " , " 4.30 ,"

February 15 th to end, March, April to August , , , 5, , " " , 5.30 ., September, , $,, \quad, 6$, October, , $, ", 5.30$, November and December, " , , 5, Also, from May lst to the middle of July, on Mondays and Saturdays only, till 8 P.M.,

and from the middle of July to the end of August, on Mondays and Saturdays only, till 7 P.M.

The Museum is open on Sunday afternoons throughout the jear. The Musoum is closed on Good-Friday and Christmas-Day.

BY ORDER OF THE TRUSTEES. 